\title{
Chapter 7 \\ The Impact of Fisheries Discards on Scavengers in the Sea
}

\author{
Jochen Depestele, Jordan Feekings, David G. Reid, Robin Cook, \\ Didier Gascuel, Raphael Girardin, Michael Heath, Pierre-Yves Hernvann, \\ Telmo Morato, Ambre Soszynski, and Marie Savina-Rolland
}

\begin{abstract}
A scavenger is an animal that feeds on dead animals (carrion) that it has not killed itself. Fisheries discards are often seen as an important food source for marine scavengers so the reduction of discards due to the Landing Obligation may affect their populations. The literature on scavenging in marine ecosystems is considerable, due to its importance in the trophic ecology of many species. Although discards undoubtedly contribute to these species' food sources, few can be seen to be solely dependent on carrion (including discards). Ecosystem models predicted that discards contributed very little to the diet of scavengers at a regional scale. A reduction in discards through the Landing Obligation may therefore affect
\end{abstract}

Electronic supplementary material The online version of this chapter (https://doi.org/10.1007/ 978-3-030-03308-8_7) contains supplementary material, which is available to authorized users.

\section{J. Depestele $(\bowtie)$}

Flanders Research Institute for Agriculture, Fisheries and Food (ILVO), Oostende, Belgium e-mail: jochen.depestele@ilvo.vlaanderen.be

J. Feekings

National Institute of Aquatic Resources, DTU Aqua, Technical University of Denmark, Hirtshals, Denmark

D. G. Reid

Marine Institute, Oranmore, County Galway, Ireland

R. Cook $\cdot$ M. Heath

Department of Mathematics and Statistics, University of Strathclyde, Glasgow, UK

D. Gascuel · P.-Y. Hernvann

Université Bretagne Loire, Agrocampus Ouest, UMR 985 Ecology and Ecosystem Health, Rennes, France

R. Girardin

Ifremer, Channel and North Sea Fisheries Research Unit, Boulogne sur Mer, France

T. Morato $\cdot$ A. Soszynski

Marine and Environmental Sciences Centre (MARE), Institute of Marine Research (IMAR) and OKEANOS Research Unit, Universidade dos Açores, Horta, Portugal

M. Savina-Rolland

Ifremer, Fishery Technology and Biology Laboratory, Lorient, France 
populations for a few species in some areas, but generally this is unlikely to be the case. But it is challenging to identify how important discards might be to scavengers, as they are taxonomically diverse and vary in the role they play in scavenging interactions.

Keywords Carrion · Discard consumption · Food subsidies · Food web models · Scavengers

\subsection{Introduction}

Trophic interactions are increasingly recognized as an important driver of ecosystem change (Pikitch et al. 2004; Möllman et al. 2015). Foraging relationships primarily focus on predator-prey interactions while the consumption of carrion, as a highquality form of dead animal matter, has received far less attention in the ecosystem context. There is considerable literature at the experimental level, but very few studies have brought this information to the higher level of assessing the actual role of discards/carrion in the marine food web. Carrion consumption should however have different consequences for the structure and functioning of food webs than predation, because it does not cause direct mortality or demographic changes (Wilson and Wolkovich 2011).

A scavenger is an animal that feeds on dead animals (carrion) that it has not killed itself (Dictionary 2018). Obligate scavengers are those that rely on carrion for survival and reproduction. Facultative scavengers are those species that will scavenge, but do not depend solely on carrion for their survival or reproduction (Beasley et al. 2015). On land, vultures are believed to be the only obligate vertebrate scavengers (DeVault et al. 2016). In the sea some benthic scavengers (e.g., hagfish, Lysianassidae amphipods) may also be obligate scavengers (Kaiser and Moore 1999; Smith and Baco 2003; Beasley et al. 2012). Facultative scavengers, in contrast, are widely present in the marine environment and range from nematodes to crustaceans, echinoderms, molluscs, fish and marine mammals (Jensen 1987; Luque et al. 2006).

Apart from whale deaths, recordings of naturally-occurring marine carrion in the sea are limited (Britton and Morton 1994; Smith and Baco 2003). The lack of naturally-occurring carrion may be due to few animals dying from natural senescence (Britton and Morton 1994) or to their rapid consumption by scavengers (Kaiser and Moore 1999). Fisheries produce non-discarded carrion due to mortality in the tow path or organisms escaping the capture process (Broadhurst et al. 2006; Collie et al. 2017; Hiddink et al. 2017). Marine carrion from fisheries discards was globally estimated to have been less than 5 million tonnes in 1950, rising to a peak of 18.8 million in 1989 and now less than 10 million tons per year (Kelleher 2005; Zeller et al. 2018). 
Fisheries discards are often perceived as an important source of food for marine scavengers that may be lost if discarding stops. A decline in European fisheries discards is currently envisaged with the gradual phasing in of the Landing Obligation (EU 2013). Such a lack of discards may have knock-on effects on seabird populations and communities (Votier et al. 2004; Bicknell et al. 2013) and this may also be true for non-avian marine scavengers, depending on their position along the obligate-to-facultative scavenging continuum.

This chapter focuses on scavengers in the sea rather than scavenging by seabirds. Two approaches were used to assess the impact of discards on scavengers in the sea: (1) a review of knowledge from field observations and (2) modelling studies. Noticeably, the review of field observations (Sect. 7.2) is less directly dealing with the EU Landing Obligation itself compared to other chapters of this book. But this study represents the first published synthesis on the fundamental knowledge on the biological and ecological processes involved in scavenging, and thus provides a very comprehensive and novel overview on the resilience of scavengers in the sea and on their potential ability to switch to other food sources if fisheries discards are reduced. This improved understanding of the processes involved will then be useful for a more accurate parameterization of the ecosystem models presented in the second part of this chapter. The final section of this chapter 'Synthesis and outlook' summarizes information about discard-scavenger interactions and how to progress knowledge on this topic.

\subsection{Field Observations of Discard-Scavenger Interactions}

Fisheries discards are considered to be an important food source for marine scavengers in the sea (e.g. Link and Almeida 2002; Fondo et al. 2015). Several field studies have been conducted using various observational techniques in various locations and seasons (Yamamura 1997; Groenewold 2000). Here we review these studies and empirical information with the overall objective of (1) identifying scavenger taxa and (2) scaling scavenger taxa along the continuum of obligate to facultative scavenging. In Sect. 7.2.4, we discuss the relevance of these observational studies to the assessment of discard-consumer candidates and highlight current knowledge gaps.

\subsubsection{Methodological Approach}

\subsubsection{List of Observational Studies}

We listed observational studies that identified organisms that are attracted to discards or to marine carrion (presented as a proxy for discards). Most of the reviewed studies used baited traps or lines $(N=16)$ or baited video frames $(N=16$; Fig. 7.1) 


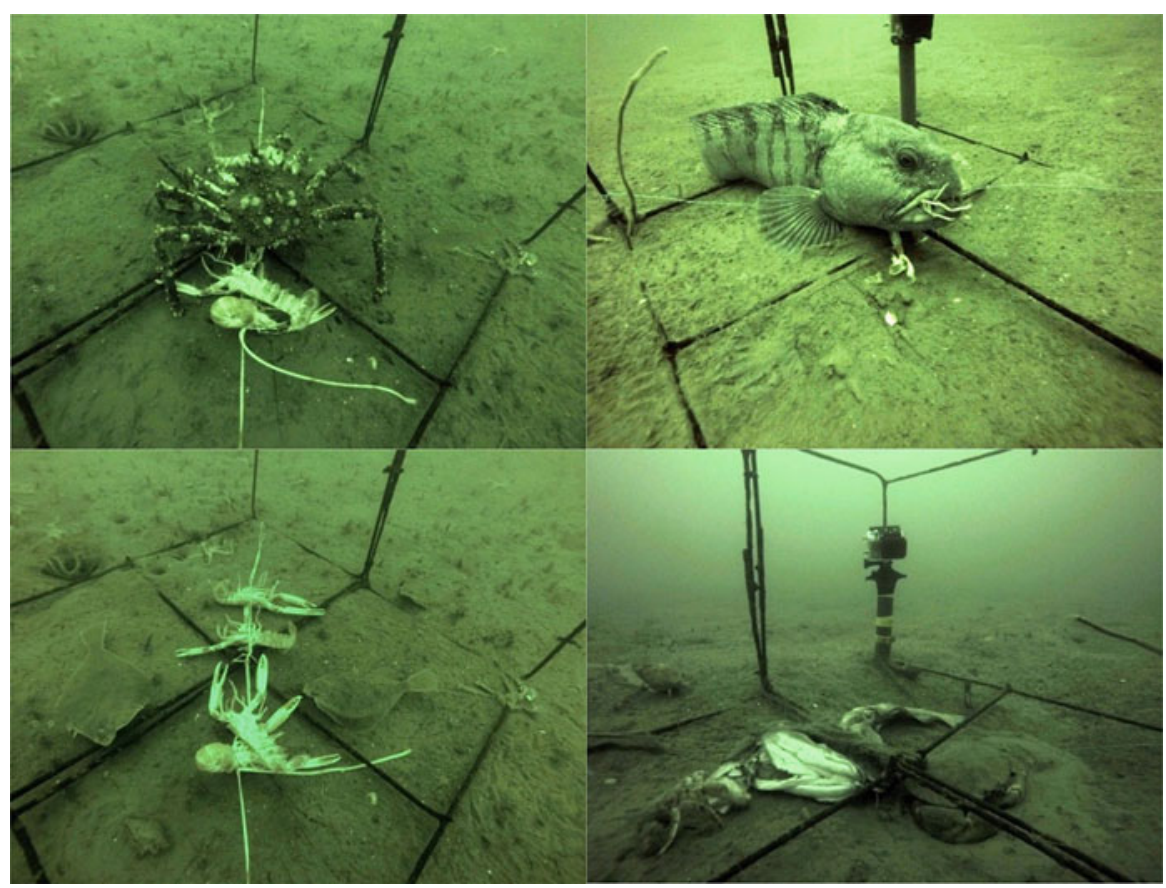

Fig. 7.1 Images taken from a baited camera trial in the Kattegat. (Photo courtesy Feekings, unpublished data; Feekings and Krag 2015)

to observe interactions between scavengers and marine carrion. Alternative observational techniques made use of laboratory observations $(N=8)$, stomach analyses $(N=6)$ or divers $(N=3)$. We also included seven studies that investigated aggregations, increased abundances or stomach contents of scavengers after the passage of a trawl, including the reaction of scavengers to carrion produced in the tow path and/or carrion from discards (Kaiser and Hiddink 2007). Three field studies on scavenging at ghost fishing nets have also been listed (Gilman 2015). These observations were complemented with studies of interactions between surface scavengers and discards from spatial interaction analysis in combination with direct observations by eye or using remote sensing systems with GPS-referenced data (Bicknell et al. 2016). The extensive series of observational studies are documented in Table 7.A of the Electronic supplementary material ${ }^{1}$ to this chapter.

The majority of the studies were done in Europe and thus have a direct relevance to the EU discard policy (30 out of 43 studies). Most studies were conducted at or near the seabed $(N=39$, with one in the intertidal zone), with three studies in the mesopelagic zone and only four studies at the water surface; 20 studies were done on

\footnotetext{
${ }^{1}$ Table 7.A in the Online Supplement refers to an extensive overview of studies investigating interactions between discards and scavengers.
} 
the continental shelf and 6 in deep sea areas (> $500 \mathrm{~m})$. The number of studies in the various depth zones of the sea (surface, mesopelagic and bentho-demersal zone) suggest how much aquatic scavenging activity is occurring in each zone. The limited number of studies in the mesopelagic zone is partly due to high sinking rates of the carrion, although it may also reflect the difficulty in studying carrion-scavenger interactions in that zone.

\subsubsection{Review of Empirical Information and Observational Studies}

Empirical information and observational studies were reviewed in two steps to address the objectives of: (1) scavenger identification and (2) scavenger scaling along the obligate to facultative scavenging continuum.

\section{Scavenger Identification}

Primary scavenger taxa from observational studies were identified (Table 7.A in the Online Supplement). This list of scavenger taxa complements the species enumeration from Britton and Morton (1994) with recent studies (1990-2017) but requires caution in determining the relative importance of different scavenger groups as consumers of marine carrion, because the different techniques used have technical constraints in determining species composition. The retention efficiency and mesh sizes of the different types of traps, for instance, may cause bias in the observed abundances.

The list of scavenger species from observational studies were complemented using data from commercial baited fisheries. Species were listed as scavenger species when annual landings between 2003 and 2016 exceeded 1 ton in ICES Subdivisions IV and VII a, d, f and VIIg. This list of species excluded discarded taxa. Discard data were available from French and UK longline fisheries (Da Silva 2009; Cornou et al. 2015). A list of species which are highly discarded (more than half of the catch) was provided for the French and UK commercial baited fisheries. These species generally comprise $<10 \%$ of the total catch of all species combined (in weight).

\section{Assessing Scavenger Abilities}

The variety of species covered in the overview of field studies (Table 7.A in the Online Supplement) and the species from commercial baited fisheries highlighted recurrent characteristics across all scavengers in the sea: from the surface into the seabed and from marine mammals to infaunal invertebrates. The overview showed that a vast range of marine aquatic taxa utilize a scavenging lifestyle to a lesser or greater extent along the facultative-obligate scavenging continuum.

Species that rely on scavenging to sustain substantial portions of their diets must encounter a sufficient amount of carrion and must be able to out-compete potential competitors and efficiently assimilate carrion to meet their energetic requirements (Ruxton et al. 2014; Kane et al. 2017). We summarized the suite of biological and functional traits that increase carrion discovery and monopoly (Table 7.A in the Online Supplement) because these traits can be used to assess any organism's ability 
to scavenge, i.e. to scale an organism along the obligate to facultative scavenging continuum.

A scale of scavenging was developed to predict the qualitative importance of carrion in a scavenger's diet (DeVault et al. 2003; Kane et al. 2017) and to partition the encountered carrion between scavenging taxa. This approach is analogous to the partitioning of fisheries discards between aerial and aquatic scavengers, which is presented in Depestele et al. (2016).

Two principal parameters of optimal foraging strategy were used to this end: (1) encounter probability and (2) handling tactics.

1. Encounter probability is the likelihood to come across carrion or fisheries discards. Carrion availability is, in general, relatively unpredictable, ephemeral and of short duration (Britton and Morton 1994; Kaiser and Moore 1999; DeVault et al. 2003; Yang et al. 2010). Scavengers can either scan vast areas at low metabolic cost to detect carrion or have limited home ranges where carrion is regularly produced and rapidly detected and encountered (Schlacher et al. 2013; Moleón et al. 2014). Four traits are presented to assess whether an organism is likely to find carrion quickly: home range, detection ability, locomotion and metabolism, the latter is the rate at which animals expend energy in relation to its acquisition (via feeding) (Brown et al. 2004). Scavengers are expected to reduce energetic maintenance costs to allow for longer inter-feeding periods (Kane et al. 2017).

2. Upon encountering carrion, scavengers require handling tactics to overcome competitors and maximize nutrient gains during feeding so that they can replenish their reserves until the next, unpredictable discovery of carrion (Ruxton and Houston 2004). Two traits, i.e. competitive abilities and capacity to facilitate the consumption of the encountered carrion, are presented to evaluate whether an organism is well fitted to scavenge.

Both parameters must occur to promote an organism's ability to find and consume carrion like fisheries discards (Depestele et al. 2016). The traits within each parameter do not necessarily work multiplicatively or additively, but taken together, they make up a qualitative scale of scavenging abilities that can be applied to any species to assess the likely relative encounter and consumption of carrion in relation to other scavenging taxa (Greene, 1986; Kane et al. 2017).

\subsubsection{Identification of Scavenging Taxa}

\subsubsection{Observational Studies}

A few studies highlight the importance of marine mammals as surface scavengers (killer whales, dolphins and seals), but most studies focused on the identification of taxa in association with the seabed. Demersal fish scavengers that were identified in more than ten field studies in Table 7.A in the Online Supplement included the 
orders Gadiformes and Perciformes. Interestingly, both orders also occurred frequently in longline landings (Sect. 7.2.2.2). Gadiformes covered several families: Gadidae (e.g. Gadus morhua, Merlangius merlangus), Merluccidae (e.g. Merluccius merluccius), Lotidae (e.g. Molva molva), Moridae (e.g. Antimora rostrata) and Macrouridae (e.g. Macrourus holotrachys). Perciformes also occurred frequently and were represented by several families: Sparidae, Labridae, Callionymidae, Zoarcidae, Trachinidae, Scombridae, Gobiidae. Fish taxa that were observed in fewer studies $(N=4-10)$ or in longline discards (see below) were sharks belonging to the Carcharhiniformes (e.g. Scyliorhinus canicula), or taxa from the orders Myxiniformes (hagfishes), Anguilliformes (e.g. Conger conger), Pleuronectiformes (e.g. Limanda limanda) and Scorpaeniformes (e.g. Triglidae). Rajiformes and Squaliformes occurred in less than four studies.

Invertebrate taxa were dominated by Decapoda, in particular Brachyura $(>10$ studies) like Cancer pagurus, Hyas araneus, Maja spp. and portunid crabs (e.g. Carcinus maenas, Liocarcinus spp. and Necora puber). Amphipoda (Orchomene spp., Scopelocheirus hopei), Isopoda (e.g. Natatolana borealis), Asteroidea (e.g. Asterias rubens), Ophiuroidea and Neogastropoda (in particular Buccinidae and Nassariidae) were also attracted to bait in at least ten studies. Taxa encountered in fewer studies $(N=3-10)$ were Cephalopoda, as well as hermit crabs, lobsters and shrimps, i.e. Decapoda belonging to the Anomura (Paguroidea, e.g. Pagurus bernhardus), Nephropoidea (e.g. Homarus gammarus and Nephrops norvegicus) or the Caridea (e.g. Crangon crangon). Polychaeta and Nemertea were identified in less than three studies, which is likely due to the mesh sizes used in the sampling methods. Landings from pot fisheries highlighted the importance of brachyuran Decapoda, whelks (Buccinum undatum) and Cephalopods.

\subsubsection{Commercial Baited Fisheries}

Scavenger species from landings data of commercial baited fisheries are listed in Table 7.1. Species which were discarded in French and UK commercial baited fisheries were: Conger conger, sharks and ray species (Galeus melastomus, Mustelus spp., Raja undulata, Scyliorhinus spp.) and quota-limited species like Brosme brosme, Helicolenus dactylopterus, Phycis blennoides or Micromesistius poutassou.

\subsubsection{Assessing Scavenger Abilities}

\subsubsection{Encounter Probability: Home Range}

Most marine organisms exhibit site fidelity, i.e. their movements are directed and confined to a smaller area rather than random. Routine activities like resting, spawning and feeding are done in established areas, defined as their home range (Pittman and McAlpine 2003). Home ranges are related to foraging strategies which 
Table 7.1 Landings of commercially valuable scavenger species from pot and longline fisheries between 2003-2016, extracted from fisheries data collection website (JRC 2018)

\begin{tabular}{|c|c|c|c|}
\hline & Scientific name & Common name & $\begin{array}{l}\text { Mean annual landings } \\
\text { (tons) }\end{array}$ \\
\hline \multirow[t]{8}{*}{ Pot fisheries } & Cancer pagurus & Edible crab & 233 \\
\hline & Buccinum undatum & Common whelk & 232 \\
\hline & Homarus gammarus & European lobster & 27 \\
\hline & Maja squinado & Spinous spider crab & 12 \\
\hline & Necora puber & $\begin{array}{l}\text { velvet swimming } \\
\text { crab }\end{array}$ & 9 \\
\hline & Sepiidae, Sepiolidae & Cuttlefishes, & 6 \\
\hline & Sepia officinalis & Common cuttlefish & 2 \\
\hline & Carcinus maenas & Shore crab & 2 \\
\hline \multirow{8}{*}{$\begin{array}{l}\text { Longline } \\
\text { fisheries }\end{array}$} & Scomber scombrus & Mackerel & 22 \\
\hline & $\begin{array}{l}\text { Merluccius } \\
\text { merluccius }\end{array}$ & Hake & 12 \\
\hline & Gadus morhua & Atlantic cod & 4 \\
\hline & Dicentrarchus labrax & Seabass & 3 \\
\hline & Molva molva & Ling & 2 \\
\hline & Pollachius pollachius & Pollack & 2 \\
\hline & Squalus acanthias & Spiny dogfish & 2 \\
\hline & Conger conger & Conger eel & 2 \\
\hline
\end{tabular}

are broadly categorized as (1) scavengers employing a sit-and-wait strategy and (2) those actively foraging in search of carrion, the free-ranging strategy (Greene 1986; Higginson and Ruxton 2015).

The nature of the sit-and-wait strategy confines the home range of the scavenger to a smaller radius of activity. Carrion detection of 'sit-and-wait' scavengers typically requires well-developed sensory capabilities (Sect. 7.2.3.2) but offers in return the advantage of refuge from predation and low metabolic costs (Løkkeborg et al. 2000; Bailey and Priede 2002). Hagfishes are a primary example of fish taxa with a sedentary life style and low metabolic requirements (Lesser et al. 1997). The 'sitand-wait' strategy of scavengers has been observed in field trials as they rapidly arrive at carrion e.g. snake eels (Ophichthus rufus) and amphipods (Sect. 7.2.3.3; Table 7.A in the Online Supplement). These rapid responses, reflected in short arrival times in baited experiments, have been used to model fish scavenger abundances (Bailey et al. 2007). Several amphipod and isopod species with small home ranges (Sainte-Marie 1986; Sainte-Marie and Hargrave 1987; Groenewold and Fonds 2000; Johansen 2000) are candidates that quickly respond to odour plumes (Tamburri and Barry 1999).

Free-ranging scavengers typically occupy larger areas to search for food and may apply a range of search techniques to encounter carrion. Bailey and Priede (2002) described two techniques in the deep sea: (1) drifting on ambient currents and detecting carrion by the sound produced by other animals feeding and (2) crosscurrent swimming which increases the probability of detecting carrion, albeit at a 
high-energy cost. Free-ranging facultative scavengers in continental shelf areas actively forage with little, if any, knowledge of resource availability (Sims et al. 2008). When resources are sparse and patchily distributed, several species, including sharks and teleost fish, exhibit Lévy flights (where area-restricted search (ARS) behaviour is alternated with movements across longer distances to detect resources Fauchald and Tveraa 2003), while Brownian movements occur when resources are abundant (Humphries et al. 2010; Sims et al. 2012). ARS-behaviour has been observed in facultative free-ranging scavengers like plaice Pleuronectes platessa (Hill et al. 2000), cod Gadus morhua (Løkkeborg and Fernö 1999) and ling Molva molva (Løkkeborg et al. 2000) and over larger areas by Atlantic cod than by ling, which increases the probability of carrion encounters. Highly mobile generalist species like cod and sharks generally occupy larger home ranges than less mobile specialist such as gobies, Conger conger and epibenthic invertebrates like Cancer pagurus and Maja squinado (Pittman and McAlpine 2003; Pita and Freire 2011; Abecasis et al. 2014; Carlson et al. 2014). The combination of ARS-behaviour and larger home ranges increases the probability of encountering carrion that does not normally constitute part of their diet. When accounting for the spatial extent of home ranges, one should acknowledge that free-ranging scavengers may establish different areas for spawning and feeding. And feeding areas may vary further diurnally, monthly, seasonally and by animal personality, which can affect their interest in scavenging (Yamamura 1997; Hunter et al. 2005; Humphries et al. 2017; VillegasRíos et al. 2018).

\subsubsection{Encounter Probability: Detection Ability}

Foraging by fish and marine invertebrates typically consists of various phases with distinctly different characteristics (Hara 2011; Kamio and Derby 2017). The first phase, finding food, involves food detection whereby scavengers are alerted by a stimulus. Initial arousal is followed by a search, involving orienting and tracking the food source. The second phase, food selection and consumption, typically involves other mechanisms, which are discussed in Sect. 7.2.3.5.

The sensory mechanisms for distant food detection in aquatic environments are primarily olfactory (smell) and gustatory (taste), rather than vision, electro- or mechanoreception (Løkkeborg et al. 2010). Whereas terrestrial scavengers may discriminate themselves from non-scavengers by well-developed olfactory senses (Kane et al. 2017; Verheggen et al. 2017), the distinction is much less pronounced in benthic and demersal aquatic environments where visibility is much lower and olfactory search behaviour is more predominant across a variety of taxa and foraging types (Seibel and Drazen 2007; Paul et al. 2011; Puglisi et al. 2014). Also, the chemical composition of the cues does not distinguish between marine scavenging and non-scavenging taxa, as non-nutritious metabolic waste from urine or other tissues of living organisms might also signal the presence of prey. The presence of odour in water is long-lasting (hours) over long distances (hundreds of meters) and has promoted evolutionary chemoreception beyond the exclusive domain of 
scavengers. Nearly all demersal fish and benthic invertebrates use olfaction for distant food detection and respond to similar threshold levels (Kohn 1961; Croll 1983; Zimmer-Faust 1987; Hara 1994; Derby and Sorensen 2008; Hay 2011; Løkkeborg et al. 2014; Kamio and Derby 2017).

While the detection thresholds of amino acids in live prey may not be speciesspecific (Hara 1994), various species show different behaviours when presented with choices between living, damaged or dead prey (Jenkins et al. 2004; Brewer and Konar 2005). Two deep-sea scavengers for instance, the hagfish Eptatretus stouti and the amphipod Orchomenella obtusa, began searching for dead and decaying food within seconds while they did not for odours that reflected live prey (Tamburri and Barry 1999). The ratio of amino acids to ammonia decreases with increasing carrion age, which may reflect relatively decreasing nutritional quality and elicit different responses across scavenging taxa (Zimmer-Faust 1987). Fisheries discards constitute a variety of living, damaged and dead organisms (Depestele et al. 2014) and may, as such, attract scavengers along a continuum of those preferring freshly killed carrion to those depredating on merely damaged and/or live prey (Table 7.A in the Online Supplement). Dead discards could be colonized by bacteria in a few days, which will then deter certain higher-order scavengers (Burkepile et al. 2006; Hussain et al. 2013). These processes may lead to a clear succession of scavengers in deepsea environments and for larger carcasses (Smith and Baco 2003; Quaggiotto et al. 2016). In continental shelf areas, it is more likely that dead discards will not reside in the benthic environment for longer than a few days (Groenewold and Fonds 2000), and therefore primarily attract higher-order scavengers which will consume the freshly killed carrion before it can fragment by physical forces and deteriorate. Even the scraps created by wasteful feeders that macerate carrion may be fed upon by indirect feeders before becoming available to detritivores (Davenport et al. 2016).

It is therefore not so much the detection threshold of carrion which will determine whether an organism will encounter carrion or not, but rather the combination of response time following detection (see arrival times in Table 7.A in the Online Supplement) and the area of attraction. Groenewold and Fonds (2000) estimated, for instance, that the attraction areas of gadoids reached up to $1200 \mathrm{~m}^{2}$, of amphipods, hermit crabs and swimming crabs to $100 \mathrm{~m}^{2}$, of starfish, whelks, dab, shrimp and brittle stars between 10 and $100 \mathrm{~m}^{2}$ and attraction areas were less than $10 \mathrm{~m}^{2}$ for gobies, solenette, sea urchins and sandstars. Both response time and attraction area are thought to be a function of swimming abilities (Sect. 7.2.3.3), intrinsic motivation (e.g. hunger status, Moore and Howarth 1996; Laidre and Elwood 2008), local enhancement (e.g. through mucus secretion by conspecifics Lee et al. 2004) or social learning behaviour (Ryer and Olla 1992; Brown and Laland 2003) as well as a function of environmental variability (e.g. currents, substratum - Bailey and Priede 2002; Stoner 2004), diel rhythm (Bozzano and Sardá 2002) and fishery-related stimuli (e.g. acoustic cues from fishery-generated noise - Thode et al. 2007). 


\subsubsection{Encounter Probability: Locomotion}

Locomotion performance is another important driver in finding carrion, and can be considered as a trade-off between extensive searching to find carrion fast versus limited searching with extended resting times between feeding bouts (Ruxton and Bailey 2005). Sit-and-wait scavengers will typically reduce searching and invest in rapid reaction upon carrion detection. Hagfish, for instance, respond quickly to carrion (Tamburri and Barry 1999) and move fast towards it despite their limited swimming capabilities (Collins et al. 1999). In contrast to other burrowing scavengers like Nephrops norvegicus which only forage upon carrion in the vicinity of their safe burrows (Nickell and Atkinson 1995), it is likely that hagfishes aggregate close to a previous feeding area to increase the probability of carrion encounters (Martinez et al. 2011). Free-ranging scavengers, in contrast, invest to a greater extent in scanning large areas to increase probabilities of encountering carrion. This foraging strategy is efficient when they can cover vast areas at a low energetic cost (Ruxton and Bailey 2005). The high energetic cost of swimming for marine mammals for instance (Williams 1999) means that they need to trade-off metabolic costs and carrion encounter between natural foraging behaviours and scavenging upon discards following fishing vessels. Whether marine mammals adapt to a scavenging lifestyle may also vary between individuals (see examples in Table 7.A in the Online Supplement). Other large marine organisms, like sharks, have been proposed as good scavenging candidates, as their large pectoral fins are adapted to cruising swimming (Carrier et al. 2004), much like typically obligate aerial scavengers, such as vultures (Kane et al. 2017). Indeed, cruising specialists like sharks and scombrids (Videler and He 2010) appeared regularly in field trials (Sect. 7.2.2). Similarly, taxa with increased swimming abilities like Gadiformes and Perciformes occurred in a larger number of studies than orders with lower swimming speed such as Pleuronectiformes, Rajiformes and Anguilliformes (Videler and He 2010; van Weerden et al. 2014). Several field studies also showed that fish arrived first, followed by fast-moving invertebrates like decapod crustaceans and lastly by slow-moving foragers such as starfish and whelks (Table 7.A in the Online Supplement). Swimming abilities are therefore an important driver to determine an organism's ability to move towards carrion fast.

\subsubsection{Encounter Probability: Metabolism}

Animal biology and ecology depends on metabolism to fuel vital activities, such as foraging (Glazier 2014; Harrison 2017). Metabolic rate (MR) provides an objective measure to attribute cost to their activities like locomotion, predator-prey interactions and to assess what animals do compared to some optimal behaviour, i.e. a 
behaviour that maximizes one or more biological characteristics such as growth or reproductive success (Metcalfe et al. 2016a, b) or a scavenger versus a predator strategy. Body size and temperature are primary determinants of respiration (Brown et al. 2004) but once accounted for, metabolic rate also reveals much about activities like foraging and the risk of being eaten (Hirst and Forster 2013; Glazier 2014). In an interplay with locomotive performance, carrion detection and foraging time, scavengers tend to reduce metabolic requirements in contrast to their predatory counterparts. A striking example is the higher MR of shallow-living pelagic predators like gadoids and tunas using visual stimuli to locate their food and spending energy to pursuit them (Farrell 1991; Seibel and Drazen 2007). The limited likelihood of a scavenging foraging strategy in pelagic organisms is further reinforced by the division of discards into floating versus rapidly sinking carrion, reducing their incidental encounter in midwater (Harris and Poiner 1990; Croxall and Prince 1994; Bergmann et al. 2002).

Scavengers exhibit low metabolic requirements so that they can survive long periods without food and benefit from efficient assimilation of carrion when it becomes available. Sharks, for instance, have the ability to fast for weeks and focus on energy-rich carrion to replenish their expenditures (Fallows et al. 2013). Other large organisms like marine mammals have higher energy expenditures to maintain their body temperature (Williams 1999; Hirt et al. 2017) and need to tradeoff gains and costs of scavenging. Ansmann et al. (2012) showed, for instance, that dolphins preferred associations with trawlers as a reliable, easily located and large food source when fishing effort was high, but they returned to group living to find food when fishing effort reduced and costs of depredation became too high. In contrast, scavenging hagfish, amphipods, starfish and gastropods may survive long periods (4 weeks to 13 months) without food (Vahl 1984; Tamburri and Barry 1999). Lysianassoid amphipods, in particular, exhibit a sit-and-wait strategy, withstanding long periods of starvation, followed by a rapid response and localisation followed by high rates of consumption and efficient carrion utilisation (Smith and Baldwin 1982; Sainte-Marie 1992). Shallow-living demersal scavenging fish (Gadiformes, Perciformes and Pleuronectiformes) have standard metabolic rates within the same order of magnitude, while energy consumption of Anguilliformes and Myxiniformes is generally much lower (Lesser et al. 1997; Clarke and Johnston 1999; Drazen et al. 2011). Lower mass-specific standard respiration rates of slowly moving (crawling) invertebrate scavengers (including crustaceans and echinoderms) were also suggested in Brey (2010).

Besides taxonomic differences in metabolic rates, a significant decline of metabolic rate with depth was demonstrated for organisms whose activities depend on light and vision (e.g. benthopelagic fish like cod), even after adjustments for temperature and body size (Seibel and Drazen 2007; Drazen and Seibel 2007). Comparisons of the deep-sea grenadier Coryphaenoides armatus with the facultative scavenger Gadus morhua, for instance, showed the increased scavenging abilities of the grenadier moving at slow swimming speeds and with a low metabolic rate, i.e. 15-30\% lower, than similar-sized cod at similar temperatures (Ruxton and Bailey 2005). Such depth-related differences in metabolic rates were not found 
between shallow and deep-living echinoderms, benthic fish, crustaceans and cephalopods - organisms which depend less on visual interactions as do their benthopelagic counterparts.

\subsubsection{Handling Tactics: Competitive Abilities}

Scavenging typically involves a large number of individuals at the carrion and leads to a complex network of direct competition (this Section), facilitation (Sect. 7.2.3.6) and indirect processes e.g. increased or decreased predation (Oro et al. 2013; Moleón et al. 2014). Assessing an organism's competitive abilities is particularly predictive for marine scavengers, because of the short generation times of carrion pulses (Nowlin et al. 2008; Beasley et al. 2012). Indeed, baited experiments show how numerous interactions between scavengers dictate the opportunities to consume the encountered carrion (see Table 7.A in the Online Supplement and references therein). Observations from baited field trials focus primarily on competition related to small amounts of carrion as used in field studies, rather than the potentially greater amounts of carrion which become available from commercial discarding practices.

The competitive abilities of marine taxa are positively correlated to their willingness to expose themselves to risk (boldness), which greatly influences their opportunities for food consumption and, ultimately, survival (Ward et al. 2006; Hamilton 2018). Several baited experiments highlighted the trade-off between feeding preferences (e.g. by damage level of discards), nutritional status (starvation level), the risk of death by predation (e.g. risk aversion of dead conspecifics) and carrion density and distribution (McKillup and McKillup 1994; Davenport and Moore 2002; Collins and Gerald 2009; Tanner et al. 2011; Yeh and Drazen 2011). Overall, organisms with larger body sizes have a higher efficacy as scavengers than smaller individuals, which is not only because they arrive first at the carrion (Sect. 7.2.3.3), but also because they ingest carrion faster, have access to larger bodied carrion, are less prone to hyper predation and are more powerful in outcompeting with smaller organisms (Juanes 1992; Collins et al. 2005; Ward et al. 2006; Nordström et al. 2015). In response, smaller organisms have developed alternative strategies to compensate for their small body size. Small scavengers can aggregate at the carrion and outnumber competitors, e.g. abundance increases of hagfish and amphipods (Table 7.A in the Online Supplement). They may also discourage competitors, e.g. by slime excretion in hagfish (Zintzen et al. 2011) or by threat displays in crabs and fish (Davenport et al. 2016). Competition may also lead to temporal niche partitioning and successional stages of carrion feeding, which is not only driven by the differential reaction speed to carrion but also by an organism's ability to ingest it (Sect. 7.2.3.6).

\subsubsection{Handling Tactics: Facilitation}

Once the food has been encountered and competitors excluded, carrion can be selected (or rejected) for consumption. The selection and consumption of carrion 
as a food source is facilitated when overlapping with dietary preferences, and when food processing abilities of the organism are adapted to the pulsed availability of the resource. These two characteristics, (1) dietary preferences and (2) food processing, jointly determine which taxa are best able to select and consume carrion and fisheries discards.

Scavengers in baited experiments were not indiscriminately attracted to any bait type but showed differential attraction according to dietary preferences (e.g. Groenewold and Fonds 2000; Jenkins et al. 2004 in Table 7.A in the Online Supplement). Starfish, for instance, showed higher abundances and attraction to mollusc bait types, with a preference for damaged carrion (Jenkins et al. 2004; Brewer and Konar 2005). The amphipod Tryphosa nana preferred dead crustaceans (Kaiser and Moore 1999). Dietary preferences are not dictated by olfactory sensory systems only, but are influenced by gustatory, visual, electro- and/or mechanosensory stimuli in species-specific ways (Carrier et al. 2004; Derby and Sorensen 2008; Løkkeborg et al. 2014; Kamio and Derby 2017). Information on sensory systems are scarce in scavenging observations, but lessons can be drawn from observations of predators. Plaice, dab and flounder, for instance, use visual stimuli more than Dover sole to target prey (de Groot 1969). Another predator, ling, targets mobile prey more often than cod, potentially showing increased dependency on visual stimuli (Løkkeborg 1998). Elasmobranch species feeding on (live) benthic prey use electrosensory means to locate food prior to its consumption (Desender et al. 2017). The dependency on other sensory systems like electrosensory location or the dependency on the mobility of food items may reduce the relevance of marine carrion (and 'dead' discards) as a targetable food source for organisms using these feeding mechanisms.

Whether scavengers will feed upon marine carrion will in part depend on these dietary portfolios and the sensory systems to locate their food, but they will also be dictated by a species' dietary plasticity. Several examples have illustrated the dietary flexibility of birds, dolphins, fish and amphipods in response to carrion availability (Whitehead and Reeves 2005; Ansmann et al. 2012; Sinopoli et al. 2012; Oro et al. 2013; Johnson et al. 2015; Seefeldt et al. 2017).

Carrion size is another potential driver of a species' ability to consume the encountered carrion. Food size is positively related with mouth gape size in fish (Scharf et al. 2000; Johnson et al. 2012), while brachyurans prefer medium-sized food items as a trade-off between energetic gains from larger food amounts with the mechanical costs of predation on larger species (Juanes 1992; Kaiser et al. 1993).

While these studies suggest that larger scavengers are more likely to consume larger carrion, a series of studies demonstrated various strategies and techniques that scavengers deploy to profit from carrion overcoming the gape limitation. Small scavengers like amphipods, gobies and hagfish may immerse themselves into cavities of decaying animals and forage from inside out ensuring consumption of rich nutrient sources first (Kaiser and Moore 1999; Bucking et al. 2011; Polačik et al. 2015). Scavengers may also jerk or shake carrion to tear it to pieces or may, in case of larger carrion, spin around their longitudinal axis, as observed in eels (Helfman and Clark 1986) and Atlantic cod (Svendsen 2018). Sharks and brachyurans 
scavengers are particularly able to exhibit high biting or crushing forces to cut larger food items into digestible pieces (Preston et al. 1996; Huber and Motta 2004; Lucifora et al. 2009). Macerating practices are generally wasteful practices, generating easy access to food for indirect feeders (Sainte-Marie 1992), which is another frequently applied scavenging tactic (Sainte-Marie 1992; Britton and Morton 1994).

Small-sized carrion used in baited experiments is expected to be consumed within days (Table 7.A in the Online Supplement). These experiments presented small amounts of small-sized carrion in comparison to fisheries discards, where larger amounts are released at once. It is likely that not all carrion is consumed within days, leading to decay and subsequent changes in palatability of the discarded carrion. While some species like gastropods do not clearly discriminate between fresh and old carrion (Morton and Jones 2003), others (Eptatretus stouti, Pycnopodia helianthoides and Orchomene spp.) show clear preferences for dead or damaged organisms (Moore and Wong 1995; Tamburri and Barry 1999; Brewer and Konar 2005). Successional stages have been documented for large-sized carrion, like whale falls in the deep sea (Smith and Baco 2003) and in shallow waters (Glover et al. 2010; Quaggiotto et al. 2016).

The limited time window for carrion consumption (due to, for example, competition and decay) has also stimulated morphological and metabolic adaptations to maximise energy gain from carrion while minimizing handling time. Deep-sea lysianassoid amphipods, for instance, can be divided into two groups: highly specialised necrophagivores (e.g. Eurythenes gryllus) that have mandibles and guts which process food in batches, while Orchomene spp. process food in a more continuous way, and have small guts and mandibles which are not well suited for rapid food ingestion (Sainte-Marie 1992; Jones et al. 1998). Another typical scavenger, Pacific hagfish (Eptatretus stoutii), can ingest large amounts of protein which would result in high rates of post-feeding ammonia and urea excretion. Indeed, Pacific hagfish has a wide scope for ammonia and urea excretion, which allows it not only to process decomposing tissue but also to process large amounts of protein which it acquires during short-term feeding bouts (Wilkie et al. 2017).

\subsubsection{Towards Identification of the Most Likely Discard- Consumer Candidates}

Field observation studies have elucidated how various traits, and trade-offs between these traits, enable organisms to scavenge upon marine carrion. A trait-based assessment enables scaling of marine scavengers along the obligate-facultative scavenging continuum is given in Fig. 7.2. This scaling can pinpoint the scavenging taxa that will primarily make use of marine carrion (including discards) and therefore have the potential to experience a population level effect when discard levels change. As discussed in more details in Sect. 7.4, the next step of this work will thus be to perform the actual ranking of the taxa identified in Sect. 7.2.2 into the continuum, on the basis of their life history. 


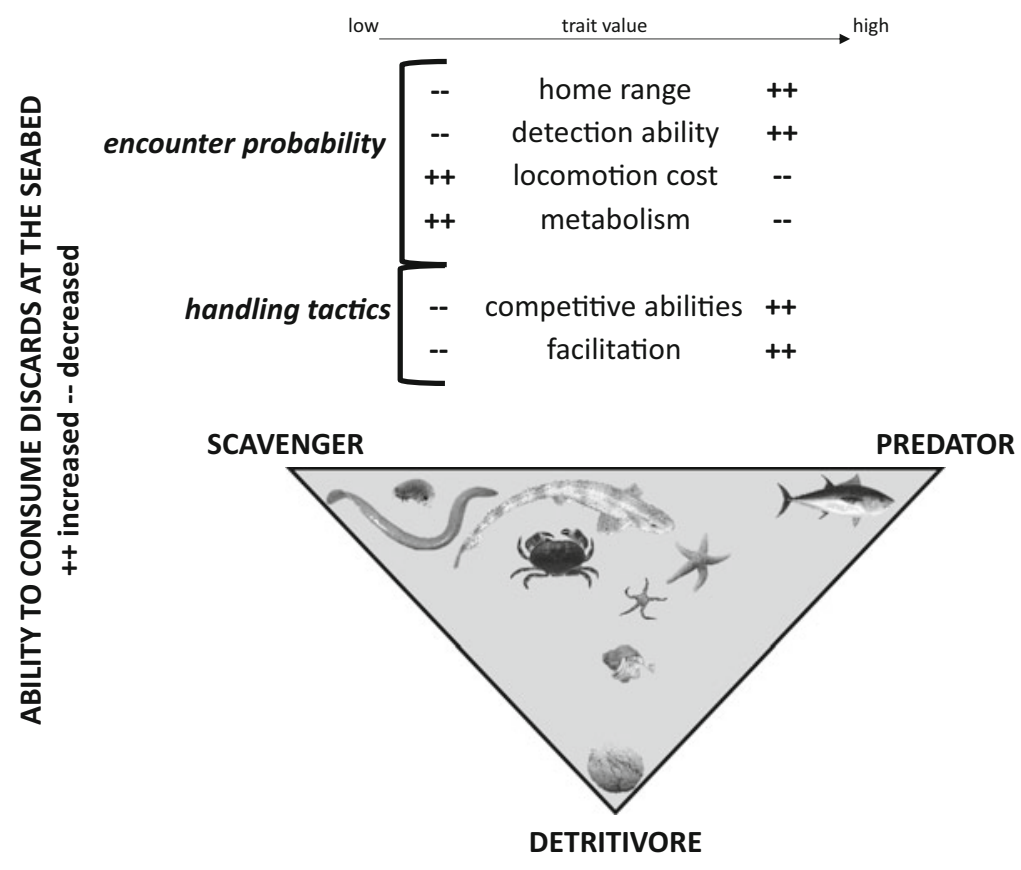

Fig. 7.2 Encounter probability and handling tactics determine an organism's scavenging ability. The traits of these two parameters make up a qualitative scale of scavenging that can be applied to any given species to assess the relative importance of carrion, including dead discards, in its diet. The ranking of species in the triangle is for illustrative purposes but does not represent a formal analysis as such. (Scavengers from left to right: hagfish and amphipod spp., dogfish and edible crab. In the centre: starfish, ophiurids and hermit crabs. Predator: tuna. Detritivore: Echinocardium spp). NB: The probability that facultative scavengers also consume fisheries discards (with more or less focus upon predation or detritivorous strategies - e.g. injured or stressed discards) was not estimated in field observation trials and requires further research. Inspired by Kane et al. (2017)

Most observational studies used marine carrion as a proxy for discards in their field tests. In general, these trials did not reflect commercial discarding practices. We acknowledge, for instance, that not all discarded organisms are dead when they are returned to the sea after commercial fishing. Foraging upon a mixture of dead, stressed, injured and potentially undamaged discarded organisms implies that discards are not only suitable as a food source to obligate scavengers, but also to predators. The consumption of stressed and injured organisms following discarding practices were less frequently examined in the observational studies but may affect foraging by facultative scavengers in commercial discarding practices.

Observational studies have also not focused on mimicking the total amount of carrion that is discarded in commercial fishing practices, nor the way it is spread or lumped on the seabed or the frequency of discard availability. Although observational studies indicated that discards are consumed in a short time window (within days), we are not aware of any observational studies underpinning these assumptions 
in relation to the recurrent high amounts of discards that become available following commercial discarding. When the assumption of rapid consumption of all discarded material does not hold in certain circumstances, we may expect that not all fisheriesinduced carrion will be consumed by scavengers. A fraction of the discards may be fragmented and become available to detritivores later.

In conclusion, field observation studies improve the qualitative assessment of the scavenging abilities of taxa on marine carrion (Fig. 7.2, upper panel). To evaluate how organisms with scavenging abilities profit from fisheries discards requires additional information, notably on the total amount of dead versus living discards and how discards are consumed by organisms with various foraging strategies. The impact of discards on marine taxa with a facultative scavenging strategy requires information on how predation and/or detritivorous strategies may influence the consumption of fisheries discards (Fig. 7.2, lower panel). Predation and detritivorous foraging strategies were not addressed in this chapter but cannot be ignored when the impact of discards as a food source for marine organisms is evaluated.

\subsection{Modelling Approaches to Discard-Scavenger Interactions}

Discarding is considered in existing ecosystem models evaluating the effects of various fisheries management measures (Fulton et al. 2014; Kaplan et al. 2014; Libralato et al. 2015; Mackinson et al. 2018), but very few have focused on exploring the effects of varying discard flows on marine food webs (Lauria 2012; Heath et al. 2014; Fondo et al. 2015). Here, we used five ecosystem models implemented across Europe to illustrate the lessons learned and challenges still ahead in modelling discard flows in marine food webs.

\subsubsection{Materials and Methods}

Three ecosystem modelling frameworks have been used: Ecopath with Ecosim (EwE), StrathE2E and Atlantis (Table 7.2). They differ in their representation of space, time and processes but all of them aim at modelling the whole food web by using functional groups (representing species sharing similar life history traits).

Five existing models were considered in this study. They are generally implemented at the scale of fisheries management regions (Fig. 7.3). The food web description in each region is specific to its general ecology, fisheries and conservation stakes (see Table 7.3 for details). However, in the outputs presented here, biomasses of functional groups were pooled in aggregated categories for the purpose of comparison. Discard flows are specific to each model and have been parameterised using data from fisheries monitoring programs. 
Table 7.2 Main features of the three modelling frameworks used

\begin{tabular}{|c|c|c|c|c|}
\hline $\begin{array}{l}\text { Model } \\
\text { type }\end{array}$ & Principle & Functional groups & Space & $\begin{array}{l}\text { More } \\
\text { details }\end{array}$ \\
\hline EwE & Mass balanced & $\begin{array}{l}\text { Biomass pool (with life } \\
\text { stanza possible) } \\
\text { Functional groups and } \\
\text { singled-out species }\end{array}$ & No & $\begin{array}{l}\text { Heymans } \\
\text { et al. } \\
(2016)\end{array}$ \\
\hline StrathE2E & \multirow{2}{*}{$\begin{array}{l}\text { Tracks the flows of nitro- } \\
\text { gen in groups of func- } \\
\text { tionally similar taxa and } \\
\text { materials, spanning the } \\
\text { entire ecosystem from } \\
\text { biogeochemistry to sea- } \\
\text { birds and marine } \\
\text { mammals }\end{array}$} & $\begin{array}{l}\text { Biomass pools (with life } \\
\text { stanza possible) }\end{array}$ & Vertical layers & $\begin{array}{l}\text { Heath } \\
(2012)\end{array}$ \\
\hline Atlantis & & $\begin{array}{l}\text { Age structured popula- } \\
\text { tion (abundance) and } \\
\text { growth (average individ- } \\
\text { ual weight) dynamic for } \\
\text { vertebrates and biomass } \\
\text { pols for invertebrates } \\
\text { Functional groups and } \\
\text { singled-out species }\end{array}$ & $\begin{array}{l}\text { Irregular hori- } \\
\text { zontal poly- } \\
\text { gons and } \\
\text { regular verti- } \\
\text { cal layers }\end{array}$ & $\begin{array}{l}\text { Fulton } \\
(2010)\end{array}$ \\
\hline
\end{tabular}
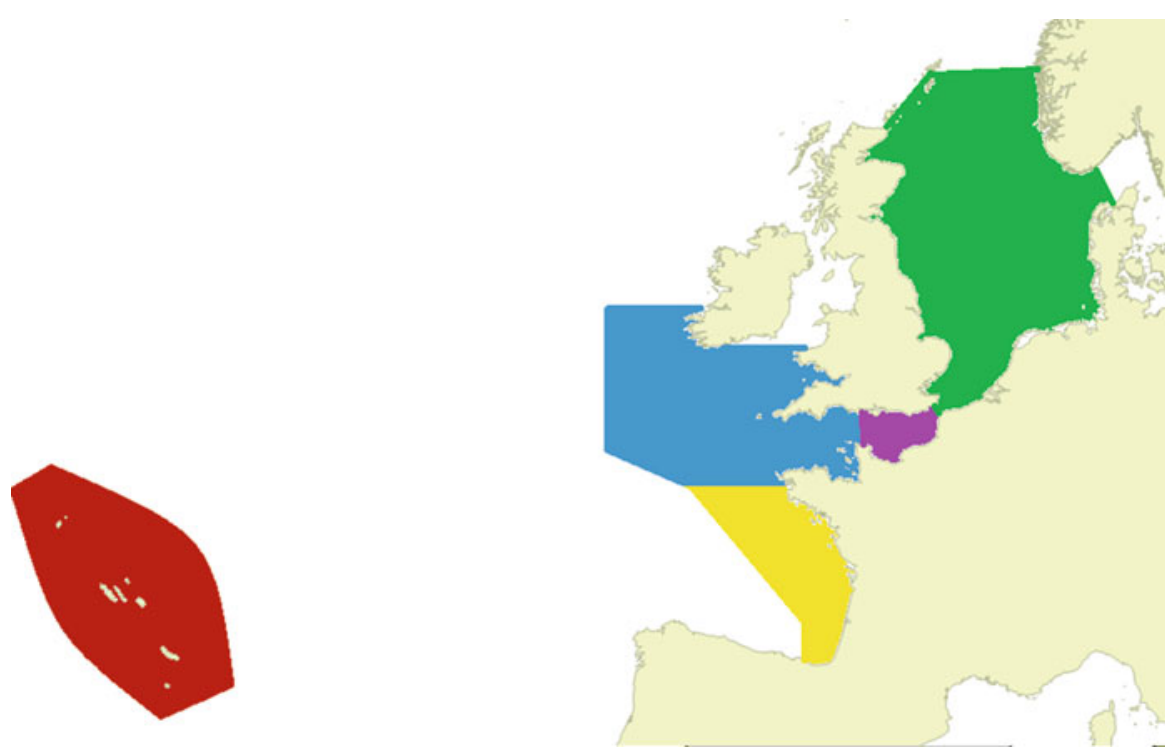

Fig. 7.3 Geographic implementation of the 5 models used: the Azores EEZ (red), the Bay of Biscay (ICES regions VIIIa and b, yellow), the Celtic Sea (VIIe, h, f, g and j, blue), the Eastern Channel (VIId), and the North Sea (IV c, b and most of a)

We evaluated two scenarios using the design in Table 7.3:

1. "Discard as Usual": fishing mortalities and discard rates are fixed per group and constant throughout the simulation, the discard survival rates are all assumed to be nil; 


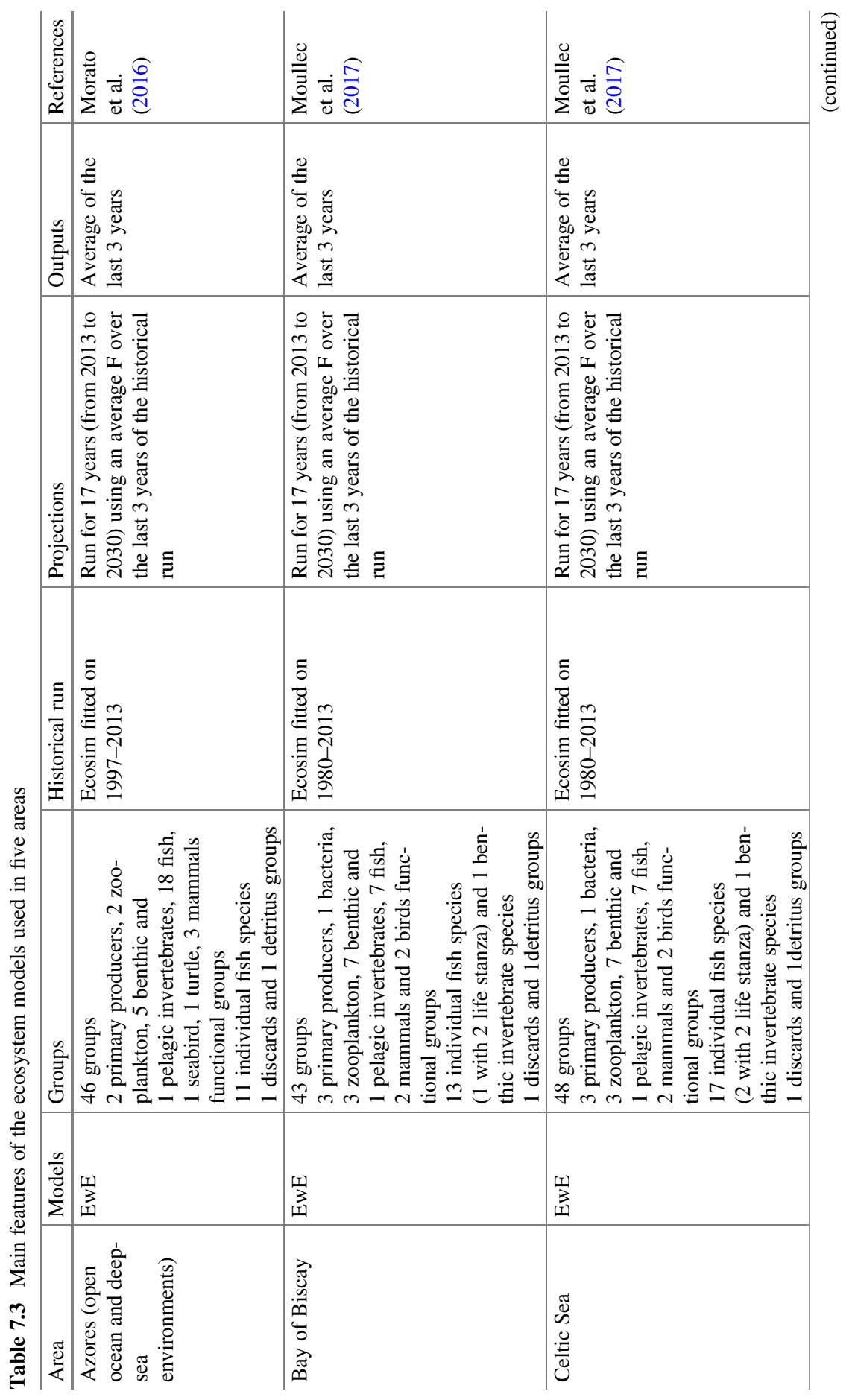




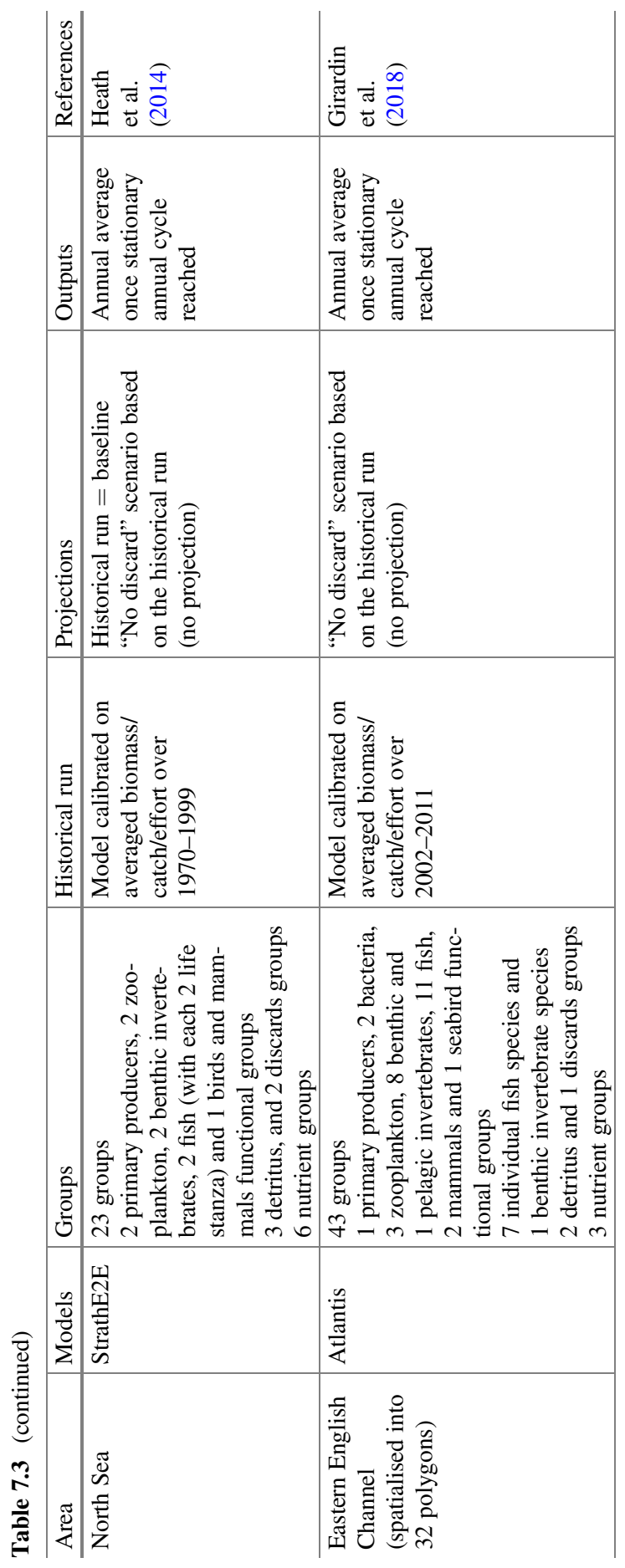




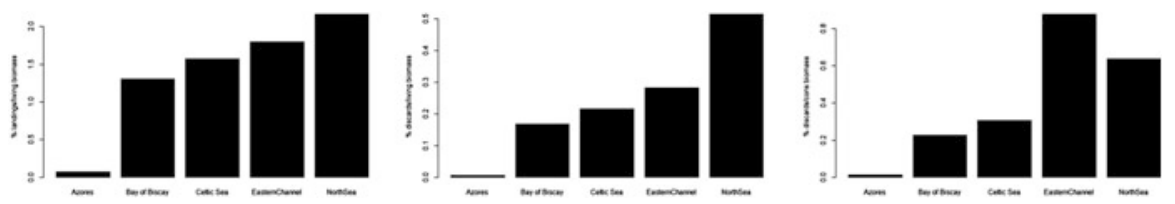

Fig. 7.4 Living biomass extracted from the ecosystem (landings) over the total biomass (left), biomass returned to the ecosystem as discards over the total living biomass (middle) and discards over total potential consumer biomass (right). The total living biomass includes vertebrates, benthic and pelagic invertebrates, benthic primary producers, as well as phytoplankton and zooplankton. The total consumer biomass includes vertebrates, benthic and pelagic invertebrates (excluding zooplankton and phytoplankton and benthic primary producers)

2. "No Discards": total fishing mortalities per group remain the same, but the discard rates are all set to 0 , leading to no discards being released in the system ${ }^{2}$, which allows one to test the 'pure' effect of the discard flow into the marine food web.

The scenarios represent extreme cases to bracket the range of possible realities and allow us to isolate the ecosystem response to the flow of discards. In the baseline model, zero survival of discarded fish is extreme, as is complete cessation of discarding in "No Discards" (especially without changes in the fishing pressure).

\subsubsection{Results}

\subsubsection{The Flow of Discards Into the Environment}

The fishing pressure varies considerably across the different modelled ecosystems, but it is apparent from Fig. 7.4 that the flow of discards into the marine ecosystem is extremely low $(<1 \%)$, when compared to the biomass of potential consumers of discards (all living groups except plankton and primary producers).

In the five models used, the actual proportion of discards in the diet of a scavenger depends on its (parameterized) preference for this type of food, and on the abundance of discards available to feed on (together with other factors depending on the model, such as spatial overlap or consumer clearance rate). Fig. 7.5 shows the average calculated diet of three groups of scavengers in the Eastern English Channel Atlantis model, among those with the highest parametrized preference for discards. The discards never accounted for more than $0.4 \%$ of the total diet, which is due to the very low abundance of discards available to consume.

\footnotetext{
${ }^{2}$ In the case of the North Sea StrathE2E model however, a residual discard flow remains for the benthos, corresponding to $4 \%$ of the baseline discard flow (Heath et al. 2014).
} 


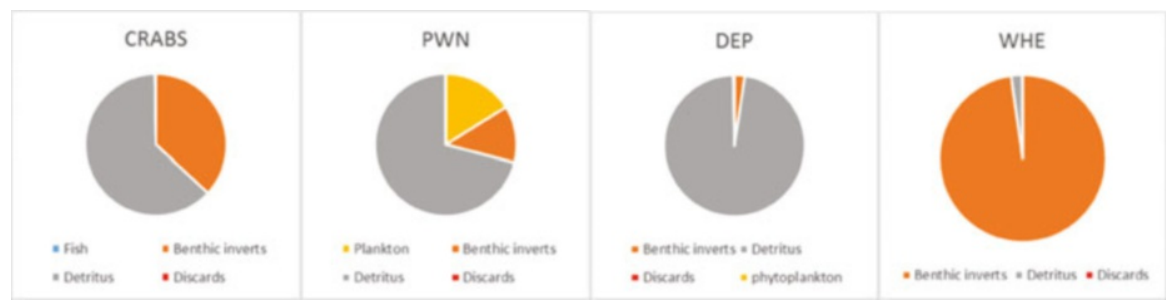

Fig. 7.5 Average diet composition of four groups of scavengers in the Atlantis Eastern English Channel model: crabs, prawns (PWN), deposit-feeders (DEP) (mainly amphipods and some polychaetes) and whelks (WHE), as calculated by the model. All the consumed food items appear in the legend, but the ones representing less than $1 \%$ of the diet do not appear on the pie charts. Benthic inverts: benthic invertebrates
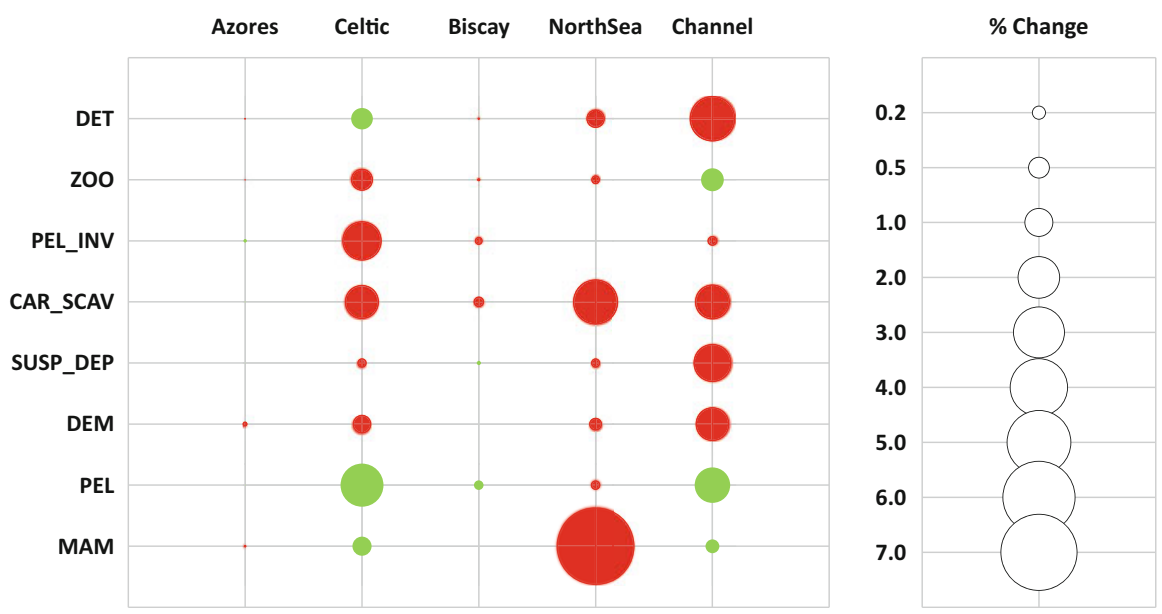

Fig. 7.6 Percentage changes in the biomass of aggregated categories between the "No Discards" scenario and the "Discard as usual" baseline. Data is shown as absolute values colored in red for negative change and green for positive change. The size of the circle is proportional to the absolute $\%$ changes in the biomass. Aggregated categories: DET: detritus, ZOO: zooplankton, PEL_INV: pelagic invertebrates, CAR_SCAV: carnivorous and scavenging benthos, SUSP_DEP: suspension and deposit feeding benthos, DEM: demersal and bentho-pelagic fish, PEL: pelagic fish, MAM: mammals

\subsubsection{Effect of Removing Discards on the Ecosystem}

Removing discards from the ecosystem had an extremely low effect on the evaluated ecosystems (Fig. 7.6), with virtually no effect $(<0.2 \%)$ on the Azores ecosystem, where the discard flow was the smallest. In the other case studies, the effect of removing discards was small but noticeable on the benthic carnivores and scavengers $(-1.3 \%$ in the Celtic Sea and $-2.4 \%$ in the North Sea). The largest negative effect of removing discards was observed in the North Sea on the mammals/seabirds 
group. Not surprisingly, the effect of removing discards is dependent on the importance of discards in the diets of the different groups.

\subsubsection{Discussion}

Discard flows may seem large when considered as absolute values, and with regards to the waste of natural resources it represents. When considered as a potential food source, however, discard flows appear to be low relative to the living biomass in the ecosystem, and when compared with other sources of food (natural carrion).

The models found little effect of a full discard ban (with no changes in the fishing pressure) on the ecosystem. These results are in agreement with other modelling studies. Sánchez and Olaso (2004) confirmed the low importance of discards as a food source in the Cantabrian Sea in comparison to detritus, primary producers or other low trophic levels $(0.07 \%$ of the total food intake, EwE model). Kaiser and Hiddink (2007) and Collie et al. (2017) estimated that fisheries-generated carrion could only sustain benthic carnivores for 3 days per year at the scale of the North Sea and scavenging fish for approximately 6 days per year. Depestele et al. (2016) similarly estimated that discards in the Grande Vasière (northern Bay of Biscay) contributed to less than $2 \%$ of the scavenging benthic community's total food requirements. Our findings are also consistent with the spatial analysis done by the Working Group on Ecosystem Effects of Fishing Activities (WGECO) of the International Council for the Exploration of the Sea (ICES) who found no relationship between discarded biomass and scavenger abundance in the North Sea (ICES 2016; ICES 2017). Other modelling studies, in contrast, found an influential effect of discards on benthic scavengers (Catchpole et al. 2006; Fondo et al. 2015) but at a smaller spatial scale (respectively Moreton Bay, and the North Sea Nephrops English fishing grounds). Ecosystem modelling can help extrapolate available data and empirical knowledge (to a certain extent) on the fate of discards in the environment at the regional scale, and in testing a full Landing Obligation scenario. However, some discrepancies between modelling and empirical knowledge should be noted. First, the discards are all pooled into one group in the models, while observational studies showed that the consumption of discards differs between the provided types of discards and dietary preferences of the scavengers (Table 7.A in the Online Supplement). Second, benthic and demersal scavengers tend to be aggregated into coarse functional groups in ecosystem models. This aggregation does not allow one to fully account for varying degrees of importance of discards to specific taxa (e.g. Sect. 7.2 of this chapter; Kaiser and Hiddink 2007; Mackinson and Daskalov 2017). Further splitting the scavenger groups would help, but only if sufficient data are available for parametrization, which is unlikely at the scale of the presented models.

A closer interaction between empirical and modelling approaches could increase our understanding of the importance of discards in the marine food web. For example, observational studies may inform modelling exercises regarding the 
differences between discard consumption ratios of taxa within one functional group. Observational studies may also set the boundaries to conduct sensitivity analyses on the existing groups, and help explore whether a different partitioning of discards as food sources across taxa results in a significant food subsidy for some species and not for others.

A major source of uncertainty in the modelling work was due to the quality of the discards data. The limited fleet coverage of discard monitoring programs hampers the possibility of discard estimations at a small spatial scale. Furthermore, current discard monitoring programs focus primarily on commercial species and have been designed to estimate discard rates per fleet and stock rather than to estimate discard flow into the environment. Reliable quantitative information on the ratio of commercial versus non-commercial discards is relatively sparse (Uhlmann et al. 2013; Depestele 2015), but existing data could be used to speculate on the orders of magnitude changes that non-commercial discards may cause in the energy flow in the ecosystem. Here again, sensitivity analyses will be necessary to complete the present work.

\subsection{Synthesis and Outlook}

There is a considerable literature about the ecology of scavenging in marine ecosystems, showing that scavenging is an important aspect of the trophic ecology of many marine species. Discards undoubtedly contribute to this with a global maximum of close to 20 million tonnes per year at its peak. Despite this, it is challenging to identify how important discards might be to the scavenging community, as they are very diverse taxonomically and in the role they play in scavenging interactions.

When marine scavengers are explicitly included as groups in ecosystem models, the impact of stopping discards is shown as minimal (Sect. 7.3). These findings corroborate earlier empirical and analytical studies where it was suggested that discards only deliver a small-scale food subsidy in large areas. They contrast, however, with a few studies (Catchpole et al. 2006) where fisheries discards may have more significant effects in certain locations with high discards

One problem with our conclusion regarding the low impact of discards is that we treated the scavenger community as a few functional groups over large spatial scales. It is more than likely that there will be particular species that are more dependent on a discard subsidy than others (Table 7.A in the Online Supplement). This was the case with small-spotted catsharks (Scyliorhinus canicula) and smooth skate (Dipturus inominatus) which made significant use of fisheries discards but not with starry rays (Raja asterias) (Forman and Dunn 2012; Navarro et al. 2016). This highlights one way in which modelling studies could be taken forward; to differentiate within the models between scavenger species that might be more, or less, dependent on discards. This would integrate improved knowledge regarding these species' relative dependencies on carrion (Sect. 7.2). It is easy to speculate, for instance, that hagfish, which consume $82 \%$ of discards would be more affected than more opportunistic 
species by banning discards. That is, it may be possible to include more categories with low to high discard dependencies within the functional groups. The trait-based approach discussed in this chapter is intended to stimulate such an assessment of scavenging abilities.

Scavenging is not only an activity of epibenthic invertebrate scavenger communities as we know that not all discards reach the seabed. Significant amounts will be consumed by marine mammals and seabirds, depending on the type of discard (Depestele et al. 2016). An unknown but likely smaller quantity will also be taken by mid water scavengers. Many demersal fish species will also likely scavenge to some extent (Table 7.A in the Online Supplement). Finally, discards may often be in large quantities locally, and may simply exceed the capacity of scavengers to utilise them all, and will then likely become available to a detritivore community. Empirical field evidence should be the main source of information to parameterise discard partitioning and usage, and therefore suggest scenarios for the models.

It is, however, important to also remain aware of the limitations of this evidence. Empirical parameterisation should be based on more than one sampling technique given the selectivity issues with observation within particular benthic and demersal environments. While numerous studies in continental European seas have highlighted what this means for benthic invertebrate scavengers, few experiments have focused on implications to fish. Also, while baited traps or cameras are excellent tools for studying which species might utilise discards and what discard types they prefer, they may not be representative of the real situation, for instance in the amount, condition or species mix of actual discards. Most importantly, these in situ methods are expensive and difficult and only provide information that is specific to a place, time and particular conditions. Extrapolating those data to population levels can be risky (Levin 1992; Dickey-Collas et al. 2014).

This brings us back to the value of the models. The models could be used in a number of scenarios to test their sensitivity to assumptions about the scavenger group. These could include giving the scavenger group a much greater dependency on discards than might otherwise be expected, and possibly finding at what level of dependency a discard ban would likely start to have effects on populations. Alternatively, we could assume a much higher level of discarding, prior to the Landing Obligation, than is suggested from observer data. Then the models could be run to show the sensitivity to the assumptions of such a high, pre-Landing Obligation discard volume. The sensitivity testing should give us some idea of what we still need to know to understand the importance of discards in the marine food web, and so the likely effects of eliminating them. This information could then be used to design subsequent field studies and analytical assessments. To date most field work has had a broad natural history approach - what do we see coming to some discarded fish? The model sensitivities could be used to define more hypothesis-based field work, focusing on particular species, discard types, places and seasons.

In conclusion, thus far, modelling and empirical studies suggest that carrion is used by many species, but few species are solely dependent on carrion (including discards). For a few species and areas, a reduction in discards due to the Landing Obligation may have a population level effect, but generally this is unlikely to be the 
case. The way forward is to determine the sensitivities in the models to certain assumptions, particularly in the importance of discards to some species in a broader scavenging community, and the actual volume of discards. That information can then be used to focus the field work on testing hypotheses which are tailored to particular species and/or discard volumes in particular locations, periods and fisheries where modelling predicts higher impacts of discards on scavengers.

Acknowledgments Part of this work has received funding from the Horizon 2020 Programme under grant agreement DiscardLess number 633680. This support is gratefully acknowledged. TM and AS acknowledge support by the Fundação para a Ciência e Tecnologia (FCT) strategic project UID/MAR/04292/2013 granted to MARE. TM is supported by the Program Investigador FCT (IF/01194/2013/CP1199/CT0002).

\section{References}

Abecasis, D., Afonso, P., Erzini, K. (2014). Combining multispecies home range and distribution models aids assessment of MPA effectiveness. Marine Ecology Progress Series, 513, 155-169.

Ansmann, I.C., Parra, G.J., Chilvers, B.L., et al. (2012). Dolphins restructure social system after reduction of commercial fisheries. Animal Behaviour, 84, 575-581.

Bailey, D.M., \& Priede, I.G. (2002). Predicting fish behaviour in response to abyssal food falls. Marine Biology, 141: 831-840.

Bailey, D.M., King, N.J., Priede, I.G. (2007). Cameras and carcasses historical and current methods for using artificial food falls to study deep-water animals. Marine Ecology Progress Series, 350, 179-192.

Beasley, J.C., Olson, Z.H., Devault, T.L. (2012). Carrion cycling in food webs: Comparisons among terrestrial and marine ecosystems. Oikos, 121, 1021-1026.

Beasley, J.C., Olson, Z.H., Devault, T.L. (2015). Ecological role of vertebrate scavengers. In M.E. Benbow, J.K. Tomerlin, A.M. Tarone (Eds.), Carrion ecology, evolution and their applications, (pp. 107-127). Boca Raton/London/New York: CRC Press/Taylor \& Francis Group.

Bergmann, M., Wieczorek, S.K., Moore, P.G., et al. (2002). Utilisation of invertebrates discarded from the Nephrops fishery by variously selective benthic scavengers in the west of Scotland. Marine Ecology Progress Series, 233, 185-198.

Bicknell, A.W.J., Oro, D., Camphuysen, K., et al. (2013). Potential consequences of discard reform for seabird communities. Journal of Applied Ecology, 50, 649-658.

Bicknell, A.W.J., Godley, B.J, Sheehan, E.V. et al. (2016) Camera technology for monitoring marine biodiversity and human impact. Frontiers in Ecology and the Environment, 14, 424-432.

Bozzano, A., Sardá, F. (2002). Fishery discard consumption rate and scavenging activity in the northwestern Mediterranean Sea.ICES Journal of Marine Science, 59, 15-28.

Brewer, R., \& Konar, B. (2005). Chemosensory responses and foraging behavior of the seastar Pycnopodia helianthoides. Marine Biology, 147, 789-795.

Brey, T. (2010). An empirical model for estimating aquatic invertebrate respiration. Methods in Ecology and Evolution, 1, 92-101.

Britton, B.C., \& Morton, B. (1994). Marine carrion and scavengers. Oceanography and Marine Biology: An Annual Review. 32, 369-434.

Broadhurst, M.K., Suuronen, P., Hulme, A. (2006). Estimating collateral mortality from towed fishing gear. Fish and Fisheries, 7, 180-218. 
Brown, C., \& Laland, K.N. (2003). Social learning in fishes: A review. Fish and Fisheries, 4, 280-288.

Brown, J.H., Gillooly, J.F., Allen, A.P., et al. (2004). Toward a metabolic theory of ecology. Ecology, 85, 1771-1789.

Bucking, C., Glover, C.N., Wood, C.M. (2011). Digestion under duress: Nutrient acquisition and metabolism during hypoxia in the Pacific hagfish. Physiological and Biochemical Zoology: Ecological and Evolutionary Approaches, 84, 607-617.

Burkepile, D.E, Parker, J.D., Woodson, C.B. et al. (2006). Chemically mediated competition between microbes and animals: Microbes as consumers in food webs. Ecology, 87, 2821-2831.

Carlson, A.E., Hoffmayer, E.R., Tribuzio, C.A., et al. (2014). The use of satellite tags to redefine movement patterns of spiny dogfish (Squalus acanthias) along the u.S. East coast: Implications for fisheries management. PLOS ONE, 9, e103384.

Carrier, J.C., Musick, J.A., Heithaus, M.R. (2004). Biology of sharks and their relatives. Boca Raton: CRC Press.

Catchpole, T.L., Frid, C.L.J., Gray, T.S. (2006). Importance of discards from the English Nephrops norvegicus fishery in the North Sea to marine scavengers. Marine Ecology Progress Series, 313, 215-226.

Clarke, A., \& Johnston, N.M. (1999). Scaling of metabolic rate with body mass and temperature in teleost fish. Journal of Animal Ecology, 68, 893-905.

Collie, J., Hiddink, J.G., van Kooten, T., Rijnsdorp, A.D., Kaiser, M.J., Jennings, S., Hilborn, R. (2017). Indirect effects of bottom fishing on the productivity of marine fish. Fish and Fisheries, 18, 619-637.

Collins, A.M., \& Gerald, G.W. (2009). Attraction of flatworms at various hunger levels toward cues from an odonate predator. Ethology, 115, 449-456.

Collins, M.A., Yau, C., Nolan, C.P., et al. (1999). Behavioural observations on the scavenging fauna of the Patagonian slope. Journal of the Marine Biological Association of the United Kingdom, 79, 963-970.

Collins, M.A., Bailey, D.M., Ruxton, G.D. et al. (2005). Trends in body size across an environmental gradient: A differential response in scavenging and non-scavenging demersal deep-sea fish. Proceedings of the Royal Society B: Biological Sciences, 272, 2051-2057.

Cornou, A.S., Diméet, J., Tétard, A. et al. (2015). Observation à bord des navires de pêche professionnelle. Bilan de l'échantillonnage 2013, 1-381

Croll, R.P. (1983). Gastropod chemoreception. Biological Reviews, 58, 293-319.

Croxall, J.P., \& Prince, P.A. (1994). Dead or alive, night or day: How do albatrosses catch squid? Antarctic Science, 6, 155-162.

Da Silva, J.F. (2009). Elasmobranchs \& Commercial Fisheries around the British Isles: Spatial and Temporal Dynamics. Universidade do Porto.

Davenport, J., \& Moore, P.G. (2002). Behavioural responses of the netted dogwhelk Nassarius reticulatus to olfactory signals derived from conspecific and nonconspecific carrion. Journal of the Marine Biological Association of the United Kingdom, 82, 967-969.

Davenport, J., McCullough, S., Thomas, R.W. et al. (2016). Behavioural responses of shallowwater benthic marine scavengers to fish carrion: In A preliminary study. Marine and freshwater behaviour and physiology, (pp. 1-15). Taylor \& Francis.

de Groot, S.J. (1969). Digestive system and sensorial factors in relation to the feeding behaviour of flatfish (Pleuronectiformes). ICES Journal of Marine Science, 32, 385-394.

Depestele, J. (2015). The fate of discards from marine fisheries. PhD thesis Ghent University. Gent, Belgium. 286pp.

Depestele, J., Desender, M., Benoît, H.P., et al. (2014). Short-term survival of discarded target fish and non-target invertebrate species in the "eurocutter" beam trawl fishery of the southern North Sea. Fisheries Research, 154, 82-92.

Depestele, J., Rochet, M.J., Dorémus, G., et al. (2016). Favorites and leftovers on the menu of scavenging seabirds: modelling spatiotemporal variation in discard consumption. Canadian Journal of Fisheries and Aquatic Sciences, 73, 1-14.

Derby, C.D., \& Sorensen, P.W. (2008). Neural processing, perception, and behavioral responses to natural chemical stimuli by fish and crustaceans. Journal of Chemical Ecology, 34, 898-914. 
Desender, M., Kajiura, S., Ampe, B., et al. (2017). Pulse trawling: Evaluating its impact on prey detection by small-spotted catshark (Scyliorhinus canicula). Journal of Experimental Marine Biology and Ecology, 486, 336-343.

DeVault, T.L., Rhodes, O.E., Shivik, J.A. (2003). Scavenging by vertebrates: Behavioral, ecological, and evolutionary perspectives on an important energy transfer pathway in terrestrial ecosystems. Oikos, 102, 225-234.

DeVault, T.L., Beasley, J.C., Olson, Z.H., et al. (2016). Ecosystem services provided by avian scavengers. In D.G.W.C.H. Şekercioğlu, C.J. Whelan (Eds.), Why birds matter: Avian ecological function and ecosystem services (pp. 235-270). Chicago: University of Chicago Press.

Dickey-Collas, M., Payne, M.R., Trenkel, V.M., et al. (2014). Hazard warning: Model misuse ahead. ICES Journal of Marine Science, 71, 2300-2306.

Dictionary, o. (2018). Scavenger Meaning in the Cambridge English Dictionary. [online] Dictionary.cambridge.org. Available at: https://dictionary.cambridge.org/dictionary/english/scaven ger. Accessed 20 June 2018.

Drazen, J.C., \& Seibel, B.A. (2007). Depth-related trends in metabolism of benthic and benthopelagic deep-sea fishes. Limnology and Oceanography, 52, 2306-2316.

Drazen, J.C., Yeh, J., Friedman, J., et al. (2011). Metabolism and enzyme activities of hagfish from shallow and deep water of the Pacific Ocean. Comparative Biochemistry and Physiology Part A: Molecular \& Integrative Physiology, 159, 182-187.

EU. (2013). European Regulation No. 1380/2013 of the European parliament and of the Council of 11 December 2013 on the Common Fisheries Policy, amending Council Regulations (EC) No 1954/2003 and (EC) No 1224/2009 and repealing Council Regulations (EC) No 2371/2002 and (EC) No 639/2004 and Council Decision 2004/585/EC. Official Journal of the European Union, L354: 22.

Fallows, C., Gallagher, A.J., Hammerschlag, N. (2013). White Sharks (Carcharodon carcharias) scavenging on whales and its potential role in further shaping the ecology of an apex predator. PLOS ONE, 8, e60797.

Farrell, A.P. (1991). From hagfish to tuna: A perspective on cardiac function in fish. Physiological Zoology, 64, 1137-1164.

Fauchald, P., \& Tveraa, T. (2003). Using first-passage time in the analysis of area-restricted search and habitat selection. In Ecology (pp. 282-288). Ecological Society of America.

Feekings, J., \& Krag, L.A. (2015). Fate of discard trial [online]. Available at: http://www. discardless.eu/video/entry/fate-of-discard-trial. Accessed 20 June 2018.

Fondo, E.N., Chaloupka, M., Heymans, J.J, et al. (2015). Banning fisheries discards abruptly has a negative impact on the population dynamics of charismatic marine megafauna. PLoS ONE, 10, e0144543.

Forman, J.S, \& Dunn, M.R. (2012) Diet and scavenging habits of the smooth skate Dipturus innominatus. Journal of Fish Biology, 80, 1546-1562.

Fulton, E.A. (2010). Approaches to end-to-end ecosystem models. Journal of Marine Systems, 81, 171-183.

Fulton, E.A., Smith, A.D.M., Smith, D.C., et al. (2014). An integrated approach is needed for ecosystem based fisheries management: Insights from ecosystem-level management strategy evaluation. PLOS ONE, 9, e84242.

Gilman, E. (2015). Status of international monitoring and management of abandoned, lost and discarded fishing gear and ghost fishing. Marine Policy, 60, 225-239.

Girardin, R., Fulton, E.A., Lehuta, S., et al. (2018). Identification of the main processes underlying ecosystem functioning in the Eastern English Channel, with a focus on flatfish species, as revealed through the application of the Atlantis end-to-end model. Estuarine, Coastal and Shelf Science, 201: 208-222.

Glazier, D. (2014). Metabolic scaling in complex living systems. Systems, 2, 451.

Glover, A.G., Higgs, N.D., Bagley, P.M., et al. (2010) A live video observatory reveals temporal processes at a shelf-depth whale-fall. Cahiers de Biologie Marine, 51, 375-381.

Greene, C.H. (1986). Patterns of prey selection: Implications of predator foraging tactics. The American Naturalist, 128, 824-839. 
Groenewold, S. (2000). The effects of beam trawl fishery on the food consumption of scavenging epibenthic invertebrates and demersal fish in the southern North Sea. PhD thesis Hamburg University. Hamburg, Germany. 158pp.

Groenewold, S., \& Fonds, M. (2000). Effects on benthic scavengers of discards and damaged benthos produced by the beam-trawl fishery in the southern North Sea. ICES Journal of Marine Science, 57, 1395-1406.

Hamilton, S.L. (2018). From a sea of phenotypic traits, fast reaction and boldness emerge as the most influential to survival in marine fish. Functional Ecology, 32, 856-857.

Hara, T.J. (1994). The diversity of chemical stimulation in fish olfaction and gustation. Reviews in Fish Biology and Fisheries, 4, 1-35.

Hara, T.J. (2011). Smell, taste, and chemical sensing I Chemoreception (Smell and Taste): An Introduction A2 - Farrell, Anthony P. In Encyclopedia of Fish Physiology (pp. 183-186). San Diego: Academic Press.

Harris, A.N., \& Poiner, I.R. (1990). By-catch of the Prawn Fishery of Torres Strait; Composition and Partitioning of the discards into components that float of sink. Marine and Freshwater Research, 41, 37-52.

Harrison, J.F. (2017). Do performance-safety tradeoffs cause hypometric metabolic scaling in animals? Trends in Ecology \& Evolution, 32, 653-664.

Hay, M.E. (2011). Crustaceans as powerful models in aquatic chemical ecology. In T. Breithaupt, and M. Thiel (Eds.), Chemical Communication in Crustaceans (pp. 41-62). New York: Springer.

Heath, M.R. (2012). Ecosystem limits to food web fluxes and fisheries yields in the North Sea simulated with an end-to-end food web model. Progress in Oceanography, 102, 42-66.

Heath, M.R., Cook, R.M., Cameron, A.I., et al. (2014). Cascading ecological effects of eliminating fishery discards. Nature Communications, 5, 1-8.

Helfman, G.S., \& Clark, J.B. (1986). Rotational feeding: Overcoming gape-limited foraging in anguillid eels. Copeia, 1986, 679-685.

Heymans, J.J., Coll, M., Link, J.S., et al. (2016). Best practice in Ecopath with Ecosim food-web models for ecosystem-based management. Ecological Modelling, 331, 173-184.

Hiddink, J., Jennings, S., Sciberras, M., et al.. (2017). Global analysis of depletion and recovery of seabed biota following bottom trawling disturbance. Proceedings of the National Academy of Sciences, 114, 8301-8306.

Higginson, A.D., \& Ruxton, G.D. (2015) Foraging mode switching: the importance of prey distribution and foraging currency. Animal Behaviour, 105, 121-137.

Hill, S., Burrows, M.T., Hughes, R.N. (2000). Increased turning per unit distance as an arearestricted search mechanism in a pause-travel predator, juvenile plaice, foraging for buried bivalves. Journal of Fish Biology, 56, 1497-1508.

Hirst, A.G., \& Forster, J. (2013) When growth models are not universal: Evidence from marine invertebrates. Proceedings of the Royal Society B: Biological Sciences, 280, 20131546.

Hirt, M.R., Jetz, W., Rall, B.C. et al. (2017). A general scaling law reveals why the largest animals are not the fastest. Nature Ecology \& Evolution, 1(8), 1116-1122.

Huber, D.R., \& Motta, P.J. (2004). Comparative analysis of methods for determining bite force in the spiny dogfish Squalus acanthias. Journal of Experimental Zoology Part A: Comparative Experimental Biology, 301A, 26-37.

Humphries, N.E., Queiroz, N., Dyer, J.R.M., et al. (2010). Environmental context explains Lévy and Brownian movement patterns of marine predators. Nature, 465, 1066-1069.

Humphries, N. E, Simpson, S.J., Sims, D.W. (2017). Diel vertical migration and central place foraging in benthic predators. Marine Ecology Progress Series, 582, 163-180.

Hunter, E., Buckley, A.A., Stewart, C., et al. (2005). Migratory behaviour of the thornback ray, Raja clavata, in the southern North Sea. Journal of the Marine Biological Association of the United Kingdom, 85, 1095-1105. 
Hussain, A., Saraiva, L.R., Ferrero, D.M., et al. (2013). High-affinity olfactory receptor for the death-associated odor cadaverine. Proceedings of the National Academy of Sciences, 110, 19579-19584.

ICES. (2016). Report of the Working Group on the Ecosystem Effects of Fishing Activities (WGECO), 6-13 april 2016. 110 pp.

ICES. (2017). Report of the Working Group on the Ecosystem Effects of Fishing Activities (WGECO), 5-12 april 2017. 122 pp.

Jenkins, S.R., Mullen, C., Brand, A.R. (2004). Predator and scavenger aggregation to discarded by-catch from dredge fisheries: Importance of damage level. Journal of Sea Research, 51, 69-76.

Jensen, P. (1987). Feeding ecology of free-living aquatic nematodes. Marine Ecology Progress Series, 35, 187-196.

Johansen, P-O. (2000). Bait attraction studies on the scavenging deepwater isopod Natatolana borealis (Crustacea, Isopoda). Ophelia, 53, 27-35.

Johnson, A.F., Valls, M., Moranta, J., et al. (2012). Effect of prey abundance and size on the distribution of demersal fishes. Canadian Journal of Fisheries and Aquatic Sciences, 69, 191-200.

Johnson, A.F., Gorelli, G., Jenkins, S.R. et al.. (2015) Effects of bottom trawling on fish foraging and feeding. Proceedings of the Royal Society of London B: Biological Sciences, 282(1799), 20142336.

Jones, E.G., Collins, M.A., Bagley, P.M., et al. (1998). The fate of cetacean carcasses in the deep sea: observations on consumption rates and succession of scavenging species in the abyssal north-east Atlantic Ocean. Proceedings of the Royal Society of London. Series B: Biological Sciences, 265, 1119-1127.

JRC. (2018). Joint Research Centre (JRC) fisheries data collection web site [online]. Available at: datacollection.jrc.ec.europa.eu. Accessed 14 Feb 2018.

Juanes, F. (1992). Why do decapod crustaceans prefer small-sized molluscan prey? Marine Ecology Progress Series, 87, 239-249.

Kaiser, M.J., \& Hiddink, J.G. (2007). Food subsidies from fisheries to continental shelf benthic scavengers. Marine Ecology Progress Series, 350, 267-276.

Kaiser, M.J., \& Moore, P.G. (1999) Obligate marine scavengers: Do they exist? Journal of Natural History, 33, 475-481.

Kaiser, M.J., Hughes, R.N., Gibson, R.N. (1993). Factors affecting diet selection in the shore crab, Carcinus maenus (L.). Animal Behaviour, 45, 83-92.

Kamio, M., \& Derby, C.D. (2017). Finding food: how marine invertebrates use chemical cues to track and select food. Natural Product Reports, 34, 514-528.

Kane, A., Healy, K., Guillerme, T., et al. (2017). A recipe for scavenging in vertebrates - the natural history of a behaviour. Ecography, 40, 324-334.

Kaplan, I.C., Holland, D.S., Fulton, E.A. (2014). Finding the accelerator and brake in an individual quota fishery: Linking ecology, economics, and fleet dynamics of US West Coast trawl fisheries. ICES Journal of Marine Science, 71, 308-319.

Kelleher, K.(2005). Discards in the worlds marine fisheries. An update. FAO Fisheries Technical Paper 470. $131 \mathrm{pp}$.

Kohn, A.J. (1961). Chemoreception in Gastropod Molluscs. American Zoologist, 1, 291-308.

Laidre, M.E., \& Elwood, R.W. (2008). Motivation matters: Cheliped extension displays in the hermit crab, Pagurus bernhardus, are honest signals of hunger. Animal Behaviour, 75, 2041-2047.

Lauria, V. (2012). Impacts of climate change and fisheries on the Celtic Sea ecosystem. In Faculty of marine science and engineering (p. 249). Plymouth: University of Plymouth.

Lee, C.G., Huettel, M., Hong, J.S., et al. (2004). Carrion-feeding on the sediment surface at nocturnal low tides by the polychaete Phyllodoce mucosa. Marine Biology, 145, 575-583. 
Lesser, M. P, Martini, F.H., Heiser, J.B. (1997). Ecology of the hagfish, Myxine glutinosa L. in the Gulf of Maine I. Metabolic rates and energetics. Journal of Experimental Marine Biology and Ecology, 208, 215-225.

Levin, S.A. (1992). The problem of pattern and scale in ecology: The Robert H. MacArthur Award Lecture. Ecology, 73, 1943-1967.

Libralato, S., Caccin, A., Pranovi, F. (2015). Modeling species invasions using thermal and trophic niche dynamics under climate change. Frontiers in Marine Science, 2, 29.

Link, J.S., \& Almeida, F.P. (2002). Opportunistic feeding of longhorn sculpin (Myoxocephalus octodecemspinosus): Are scallop fishery discards an important food subsidy for scavengers on Georges Bank? Fishery Bulletin, 100, 381-385.

Løkkeborg, S. (1998). Feeding behaviour of cod, Gadus morhua: Activity rhythm and chemically mediated food search. Animal Behaviour, 56, 371-378.

Løkkeborg, S., \& Fernö, A. (1999). Diel activity pattern and food search behaviour in cod, Gadus morhua. Environmental Biology of Fishes, 54, 345-353.

Løkkeborg, S., Skajaa, K., Fernö, A. (2000). Food-search strategy in ling (Molva molva L.): Crepuscular activity and use of space. Journal of Experimental Marine Biology and Ecology, 247, 195-208.

Løkkeborg, S., Fernö, A, Humborstad, O.B. (2010). Fish Behavior in Relation to Longlines. In P. He (Ed.), Behavior of Marine Fishes: Capture processes and conservation challenges (pp. 105-141). Oxford: Wiley-Blackwell.

Løkkeborg, S., Siikavuopio, S. I, Humborstad, O.B., et al. (2014). Towards more efficient longline fisheries: Fish feeding behaviour, bait characteristics and development of alternative baits. Reviews in Fish Biology and Fisheries, 24, 985-1003.

Lucifora, L.O., García, V.B., Menni, R.C. et al (2009). Effects of body size, age and maturity stage on diet in a large shark: Ecological and applied implications. Ecological Research, 24: 109-118.

Luque, P.L., Davis, C.G., Reid, D.G., et al.. (2006). Opportunistic sightings of killer whales from Scottish pelagic trawlers fishing for mackerel and herring off North Scotland (UK) between 2000 and 2006. Aquatic Living Resources, 19, 403-410.

Mackinson, S., \& Daskalov, G. (2007). An ecosystem model of the North Sea to support an ecosystem approach to fisheries management: description and parameterisation. ICES Document Sci. Ser. Tech Rep., Cefas Lowestoft, 142. 196 pp.

Mackinson, S., Platts, M., Garcia, C., et al. (2018). Evaluating the fishery and ecological consequences of the proposed North Sea multi-annual plan. PLoS ONE, 13, e0190015.

Martinez, I., Jones, E.G., Davie, S.L., et al. (2011). Variability in behaviour of four fish species attracted to baited underwater cameras in the North Sea. Hydrobiologia, 670, 23.

McKillup, S.C., \& McKillup, R.V. (1994). The decision to feed by a scavenger in relation to the risks of predation and starvation. Oecologia, 97, 41-48.

Metcalfe, N.B., Van Leeuwen, T.E., Killen, S.S. (2016a). Does individual variation in metabolic phenotype predict fish behaviour and performance? Journal of Fish Biology, 88, 298-321.

Metcalfe, J.D., Wright, S., Tudorache, C., et al. (2016b). Recent advances in telemetry for estimating the energy metabolism of wild fishes. Journal of Fish Biology, 88, 284-297.

Moleón, M., Sánchez-Zapata, J.A., Selva, N., et al. (2014). Inter-specific interactions linking predation and scavenging in terrestrial vertebrate assemblages. Biological Reviews, 89, 1042-1054.

Möllmann, C., Folke, C., Edwards, M., et al. (2015). Marine regime shifts around the globe: Theory, drivers and impacts. Philosophical Transactions of the Royal Society of London. Series B, Biological Sciences, 370, 20130260.

Moore, P.G., \& Howarth, J. (1996). Foraging by marine scavengers: Effects of relatedness, bait damage and hunger Journal of Sea Research, 36, 267-273.

Moore, P.G., \& Wong, Y.M. (1995). Orchomene nanus (Krøyer) (Amphipoda: Lysianassoidea), a selective scavenger of dead crabs: Feeding preferences in the field. Journal of Experimental Marine Biology and Ecology, 192, 35-45. 
Morato, T., Lemey, E., Menezes, G., et al. (2016). Food-web and ecosystem structure of the openocean and deep-sea environments of the Azores, NE Atlantic. Frontiers in Marine Science, 3, 245.

Morton, B., \& Jones, D.S. (2003). The dietary preferences of a suite of carrion-scavenging gastropods (Nassariidae, Buccinidae) in Princess royal harbour, Albany, Western Australia. Journal of Molluscan Studies, 69, 151-156.

Moullec, F., Gascuel, D., Bentorcha, K., et al. (2017) Trophic models: What do we learn about Celtic Sea and Bay of Biscay ecosystems? Journal of Marine Systems, 172: 104-117.

Navarro, J., Cardador, L., Fernández, Á.M., et al. (2016) Differences in the relative roles of environment, prey availability and human activity in the spatial distribution of two marine mesopredators living in highly exploited ecosystems. Journal of Biogeography, 43, 440-450.

Nickell, L. A, \& Atkinson, R.J.A. (1995). Functional morphology of burrows and trophic modes of three thalassinidean shrimp species, and a new approach to the classification of thalassinidean burrow morphology. Marine Ecology Progress Series, 128, 181-197.

Nordström, M.C., Aarnio, K., \& Törnroos, A. et al. (2015). Nestedness of trophic links and biological traits in a marine food web. Ecosphere, 6, art161.

Nowlin, W.H., Vanni, M.J., Yang, L.H. (2008). Comparing resource pulses in aquatic and terrestrial ecosystems. Ecology, 89, 647-659.

Oro, D., Genovart, M., Tavecchia, G., et al. (2013). Ecological and evolutionary implications of food subsidies from humans. Ecology Letters, 16, 1501-1514.

Paul, V.J., Ritson-Williams, R., Sharp, K. (2011). Marine chemical ecology in benthic environments. Natural Product Reports, 28, 345-387.

Pikitch, E.K., Santora, C., Babcock, E.A., et al. (2004) Ecosystem-based fishery management. Science, 305, 346-347.

Pita, P., \& Freire, J. (2011). Movements of three large coastal predatory fishes in the northeast Atlantic: A preliminary telemetry study. Scientia Marina, 2011(75), 12.

Pittman, S.J., \& McAlpine, C.A. (2003). Movements of marine fish and decapod crustaceans: Process, theory and application. In A.J. Southward, P.A. Tyler, C.M. Young, L.A. Fuiman (Eds.), Advances in Marine Biology (Vol 44, pp. 205-294).

Polačik, M., Jurajda, P., Blažek, R., et al. (2015). Carcass feeding as a cryptic foraging mode in round goby Neogobius melanostomus. Journal of Fish Biology, 87, 194-199.

Preston, S.J, Revie, I.C, Orr, J.F, et al. (1996). A comparison of the strengths of gastropod shells with forces generated by potential crab predators. Journal of Zoology, 238, 181-193.

Puglisi, M.P., Sneed, J.M., Sharp, K.H., et al. (2014). Marine chemical ecology in benthic environments. Natural Product Reports, 31, 1510-1553.

Quaggiotto, M.M., Burke, L.R., McCafferty, D.J., et al. (2016). First investigations of the consumption of seal carcasses by terrestrial and marine scavengers. Glasgow Naturalist, 26, 33-52.

Ruxton, G.D., \& Bailey, D.M. (2005). Searching speeds and the energetic feasibility of an obligate whale-scavenging fish. Deep Sea Research Part I: Oceanographic Research Papers, 52, $1536-1541$.

Ruxton, G.D., \& Houston, D.C. (2004). Energetic feasibility of an obligate marine scavenger. Marine Ecology Progress Series, 266, 59-63.

Ruxton, G.D., Wilkinson, D.M., Schaefer, H.M., et al.. (2014). Why fruit rots: Theoretical support for Janzen's theory of microbe-macrobe competition. Proceedings of the Royal Society B 281, 20133320.

Ryer, C.H., \& Olla, B.L. (1992). Social mechanisms facilitating exploitation of spatially variable ephemeral food patches in a pelagic marine fish. Animal Behaviour 44, 69-74.

Sainte-Marie, B. (1986). Feeding and swimming of lysianassid amphipods in a shallow cold-water bay. Marine Biology, 91, 219-229.

Sainte-Marie, B. (1992). Foraging of scavenging deep-sea lysianassoid amphipods. In G.T.P.V. Rowe (Ed.) Deep-sea food chains and the global carbon cycle. Berlin/ Heidelberg/New York: Springer. 
Sainte-Marie, B., \& Hargrave, B.T. (1987). Estimation of scavenger abundance and distance of attraction to bait. Marine Biology, 94, 431-443.

Sánchez, F., \& Olaso, I. (2004). Effects of fisheries on the Cantabrian Sea shelf ecosystem. In Ecological modelling placing fisheries in their ecosystem context (pp. 151-174).

Scharf, F.S., Juanes, F., Rountree, R.A. (2000). Predator size - prey size relationships of marine fish predators: Interspecific variation and effects of ontogeny and body size on trophic-niche breadth. Marine Ecology Progress Series, 208, 229-248.

Schlacher, T.A, Strydom, S., Connolly, R.M. (2013). Multiple scavengers respond rapidly to pulsed carrion resources at the land-ocean interface. Acta Oecologica, 48, 7-12.

Seefeldt, M.A., Campana, G.L., Deregibus, D., et al. (2017). Different feeding strategies in Antarctic scavenging amphipods and their implications for colonisation success in times of retreating glaciers. Frontiers in Zoology, 14, 59.

Seibel, B.A., \& Drazen, J.C. (2007). The rate of metabolism in marine animals: Eanvironmental constraints, ecological demands and energetic opportunities. Philosophical Transactions of the Royal Society B: Biological Sciences, 362, 2061-2078.

Sims, D.W., Southall, E.J., Humphries, N.E., et al. (2008). Scaling laws of marine predator search behaviour. Nature, 451, 1098.

Sims, D.W., Humphries, N.E., Bradford, R.W. et al. (2012). Lévy flight and Brownian search patterns of a free-ranging predator reflect different prey field characteristics. Journal of Animal Ecology, 81, 432-442.

Sinopoli, M., Fanelli, E., D’Anna, G., et al. (2012). Assessing the effects of a trawling ban on diet and trophic level of hake, Merluccius merluccius, in the southern Tyrrhenian Sea. Scientia Marina, 76, 677-690.

Smith, C.R., \& Baco, A.R. (2003). Ecology of whale falls at the deep-sea floor. In R.N. Gibson, R.J.A. Atkinson (Eds.), Oceanography and marine biology, (Vol. 41, pp. 311-354).

Smith, K.L, \& Baldwin, R.J. (1982). Scavenging deep-sea amphipods: Effects of food odor on oxygen consumption and a proposed metabolic strategy. Marine Biology, 68, 287-298.

Stoner, A.W. (2004). Effects of environmental variables on fish feeding ecology: Implications for the performance of baited fishing gear and stock assessment. Journal of Fish Biology, 65, $1445-1471$.

Svendsen, J.C. (2018). Cod death roll. https://www.youtube.com/watch?v=CE_lmtIX3Bg. Accessed 20 June 2018.

Tamburri, M.N., \& Barry, J.P. (1999). Adaptations for scavenging by three diverse bathyla species, Eptatretus stouti, Neptunea amianta and Orchomene obtusus. Deep Sea Research Part I: Oceanographic Research Papers, 46, 2079-2093.

Tanner, C.J., Salah, G.L., Jackson, A.L. (2011). Feeding and non-feeding aggression can be induced in invasive shore crabs by altering food distribution. Behavioral Ecology and Sociobiology, 65, 249-256.

Thode, A., Straley, J., Tiemann, C.O., et al. (2007). Observations of potential acoustic cues that attract sperm whales to longline fishing in the Gulf of Alaska. The Journal of the Acoustical Society of America 122, 1265-1277.

Uhlmann, S.S., Coers, A., van Helmond, A.T.M., et al. (2013). Discard sampling of Dutch bottomtrawl and seine fisheries in 2012. CVO Report 13.015. 76pp.

Vahl, O. (1984). The relationship between specific dynamic action (SDA) and growth in the common starfish, Asterias rubens L. Oecologia, 61, 122-125.

van Weerden, J.F., Reid, D.A.P., Hemelrijk, C.K. (2014). A meta-analysis of steady undulatory swimming. Fish and Fisheries 15(3), 397-409.

Verheggen, F., Perrault, K.A., Megido, R.C., et al. (2017). The odor of death: An overview of current knowledge on characterization and applications. Bioscience, 67, 600-613.

Videler, J.J, \& He, P. (2010). Swimming in marine fish. In P. He (Ed.), Behavior of marine fishes: Capture processes and Conservation challenge (pp. 3-24). New York: Wiley-Blackwell. 
Villegas-Ríos, D., Réale, D., Freitas, C., et al. (2018). Personalities influence spatial responses to environmental fluctuations in wild fish. The Journal of Animal Ecology. https://doi.org/10.1111/ $1365-2656.12872$

Votier, S.C., Furness, R.W., Bearhop, S., et al. (2004). Changes in fisheries discard rates and seabird communities. Nature, 427, 727-730.

Ward, A.J.W., Webster, M.M, Hart, P.J.B. (2006). Intraspecific food competition in fishes. Fish and Fisheries, 7, 231-261.

Whitehead, H., \& Reeves, R. (2005). Killer whales and whaling: The scavenging hypothesis. Biology Letters, 1, 415-418.

Wilkie, M.P, Clifford, A.M., Edwards, S.L, et al. (2017). Wide scope for ammonia and urea excretion in foraging Pacific hagfish. Marine Biology, 164, 126.

Williams, T.M. (1999). The evolution of cost efficient swimming in marine mammals: limits to energetic optimization. Philosophical Transactions of the Royal Society of London. Series B: Biological Sciences, 354, 193-201.

Wilson, E.E., \& Wolkovich, E.M. (2011). Scavenging: How carnivores and carrion structure communities. Trends in Ecology \& Evolution, 26, 129-135.

Yamamura, O. (1997). Scavenging on discarded saury by demersal fishes off Sendai Bay, northern Japan. Journal of Fish Biology, 50, 919-925.

Yang, L.H., Edwards, K.F., Byrnes, J.E., et al. (2010). A meta-analysis of resource pulse-consumer interactions. Ecological Monographs, 80, 125-151.

Yeh, J., \& Drazen, J.C. (2011). Baited-camera observations of deep-sea megafaunal scavenger ecology on the California slope. Marine Ecology Progress Series, 424, 145-156.

Zeller, D., Cashion, T., Palomares, M., et al.. (2018). Global marine fisheries discards: A synthesis of reconstructed data. Fish and Fisheries, 19: 30-39.

Zimmer-Faust, R.K. (1987). Crustacean chemical perception: Towards a theory on optimal chemoreception. The Biological Bulletin, 172, 10-29.

Zintzen, V., Roberts, C.D., Anderson, M.J., et al. (2011). Hagfish predatory behaviour and slime defence mechanism. Scientific Reports, 1, 131.

Open Access This chapter is licensed under the terms of the Creative Commons Attribution 4.0 International License (http://creativecommons.org/licenses/by/4.0/), which permits use, sharing, adaptation, distribution and reproduction in any medium or format, as long as you give appropriate credit to the original author(s) and the source, provide a link to the Creative Commons license and indicate if changes were made.

The images or other third party material in this chapter are included in the chapter's Creative Commons license, unless indicated otherwise in a credit line to the material. If material is not included in the chapter's Creative Commons license and your intended use is not permitted by statutory regulation or exceeds the permitted use, you will need to obtain permission directly from the copyright holder.

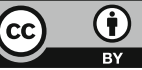

